\title{
The Immigrant Waves from Latin American to Canada: A Look at Immigration and Census Statistics ${ }^{1}$
}

Fernando Mata

School of Sociological and Anthropological Studies

University of Ottawa

fmata_uottawa@yahoo.com

December 5, 2021

\section{Abstract}

In the last decades, migration from Latin America to Canada has become a topic of interest for Canadian scholars, policy decision-makers that look after the well-being of this population as well as for community members themselves. The nature of Latino immigration to Canada is continuously changing, and so does how the integration of these immigrants to Canada is interpreted and problematized. Using yearly immigration statistics and 2016 Census data, the author looks at the 1965-2015 and 1981-2016 periods and explores the five major Latin American immigrant waves previously identified by Canadian scholars: the Eurolatino or Lead of the 1960s, the Andean and Coup of the 1970s, the Central American of the 1980s, and the Technological-Professional which started in the mid1990s. A sixth additional Sustaining Latino immigrant wave is also identified. Immigrant waves are the product of particular historical international developments as well as changes in Canada's immigration policy. The paper briefly also examines the historical moments of Latino immigration to Canada, the socio-demographic composition of national immigrant inflows related to these immigrant waves, and reflects on how the immigrant selection process has affected immigration integration outcomes and community formation.

Keywords: Latin America, Immigrant Waves, Immigration, Canada

\section{Some Terms Used in the Paper:}

Latin America: Geographical region comprising 19 Spanish and Portuguese speaking countries of North, Central America, South America, and the Caribbean, except Puerto Rico due to its special status. Nationals from these countries are referred to as Latinos in the paper.

Permanent Residents: Individuals who have been lawfully permitted to settle in Canada under the three major immigrant intake classes: economic, family, and refugee.

Immigrant Intake Class: the status of entry upon legal admission to Canada. The economic class comprises individuals such as skilled workers, business immigrants, and/or sponsored dependents of skilled dependents. The family category comprises immigrants with immediate family members already living in Canada and is required to have a sponsor (typically the family member) who has agreed to provide financial support for a period of three to ten years following arrival. The refugee category comprises three types of refugees: state-sponsored, privately sponsored, and asylum (e.g. protected persons).

\footnotetext{
${ }^{1}$ Background paper presented to the International Conference Women, Gender and Intersectionality in the Lusophone World, June 29 to July 2 , 2022, Ponta Delgada, Azores, Portugal. The author would like to thank Jennifer Dumoulin and the Census Division of Statistics Canada for making available the data and their valuable support and guidance.
} 
Country of Citizenship: A country where the person has citizenship. Citizenship can be obtained by birth or naturalization.

Ethnic Origin: The ethnic or cultural origins of the person's ancestors. An ancestor is usually more distant than a grandparent (2016 Census of Canada). The 2016 census allows for the reporting of both single (e.g. Colombian) and multiple origins (e.g. Colombian and Spanish).

Immigrant Waves: Central population movements drawn from the Latin America geographical region to Canada by immigration processes due to a combination of various push-pull factors.

Immigration and Census Statistics: data sources used for this analysis. Immigration statistics are drawn from special tables of the former Department of Employment and Immigration as well as the Facts and Figures publication of yearly admissions to Canada (Immigration, Refugees and Citizenship Canada). Census statistics comprise special tabulations from the 2016 Census: tables EO2680, EO2695, and EO3181 respectively. These were specially prepared for the author by Statistics Canada.

\subsection{Immigrant Waves Typology}

The history of Latin American immigration to Canada cannot be fully understood without some reduction of its tremendous complexity to essential basic features (e.g. the central population movements coming from the region). This reduction entails an examination of the socio-demographic composition of these movements, major push-pull drivers, and also contextual factors such as Canadian immigration policy changes (Simmons, 1993; Armony, 2014). From a broad perspective, the concept of immigrant waves becomes a useful descriptive tool to situate the various immigrant inflows in a historical context. The concept of immigrant waves taps into domains related both to the amplitude of the phenomena (i.e. range of countries and the types of individuals involved) and also its historical cycles (i.e. "peaks" and "valleys" of immigrant intake). Immigrant waves from Latin America to Canada have manifested themselves in various fashions and they are presumed not to be necessarily cumulative. Various source countries have participated in waves at different time points. Although each wave is closely tied to particular international and domestic events, these events most likely exacerbated processes already in progress rather than determined them.

In 1985, the author developed a socio-demographic typology that identified the first four major waves coming from the Latin American region: Eurolatino (also called "Lead"), Andean, Coup, and Central American. After the Eurolatino and Andean waves, which were essentially rooted in economic and political developments taking place in Canada, violence, and repression were largely responsible for migratory movements in the early and mid-1970s and 1980s. Military coups brought thousands of highly educated immigrants from Southern Cone countries such as Chile, Argentina, and Uruguay, while the Central American Civil War drew a wide spectrum of urban and rural workers from countries such as El Salvador, Guatemala, and Nicaragua (Mata, 1985; 2020). More recently, several Canadian scholars have identified a fifth major wave (Technological-Professional) which was triggered around the mid-1990s². Countries such as Colombia, Mexico, Venezuela, Cuba, and Brazil are representative of this latter wave. An interpretative diagram of these immigrant waves produced by the author is provided in Chart 1 .

\footnotetext{
2 See for instance: Veronis, 2010; Landolt, Bernhard and Goldring, 2011; Goldring and Landolt, 2021.
} 
Chart 1: Interpretative Diagram: Five Major Immigrant Waves from Latin America to Canada and Their Most Representative Countries of Origin (Source: Mata, 2020)

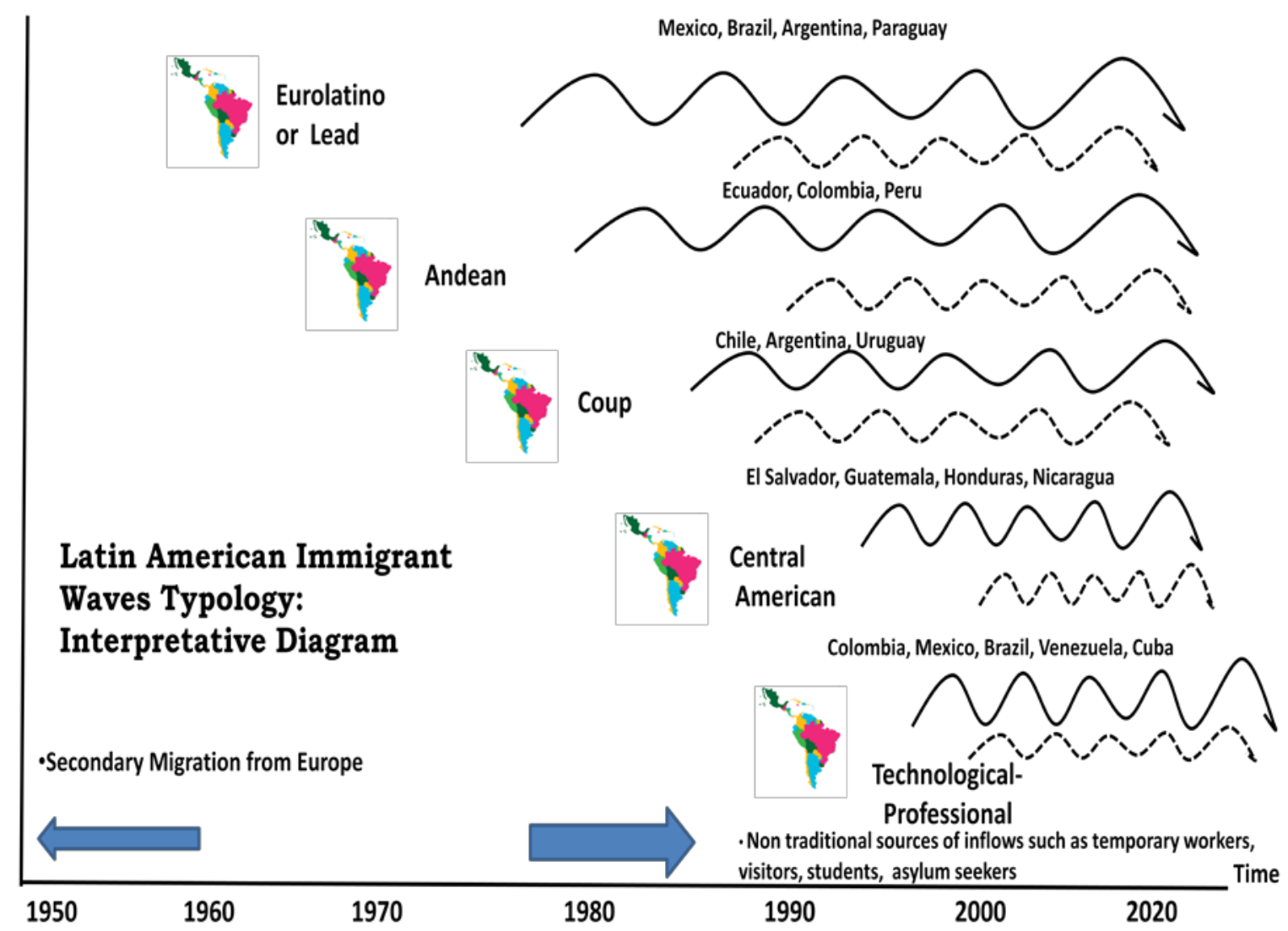

\subsection{Immigration Data Explorations: The 1965-2015 Period}

The 1965-2015 period is an important historical juncture characterized by the extraordinary growth of the Latino immigrant population in Canada. Nearly half a million individuals entered Canada as permanent residents from the major 19 countries of the region. More importantly, it is in these years that the five major Latin American immigrant waves consolidated their presence in the country. This consolidation occurred within a domestic context of economic "booms" and "busts" and the alternation of liberal and conservative administrations which chose various plans and goals for their respective immigration policies. Over time, Canada gradually moved from guiding principles based on concepts such as "absorptive economic capacity" to that of "manpower recruitment", "family reunification" and "refugee protection". The introduction of IRPA in 2002 (Immigration and Refugee Protection Act) was pivotal in defining more clearly the national immigration policy goals to pursue and the granting of refugee protection to persons who are displaced, persecuted, or in danger. Piché (2019) argues that today, Canadian policy is shaped within the international context of the Trump era of "Reja-Muro", progressively moving towards a more "utilitarian" approach benefiting economic types of migration rather than social or humanitarian ones (temporary workers and/or entry of highly qualified permanent residents). 
Chart 2: Admissions of Permanent Residents by Country of Citizenship, 19 Latin American Countries, 1965-2015

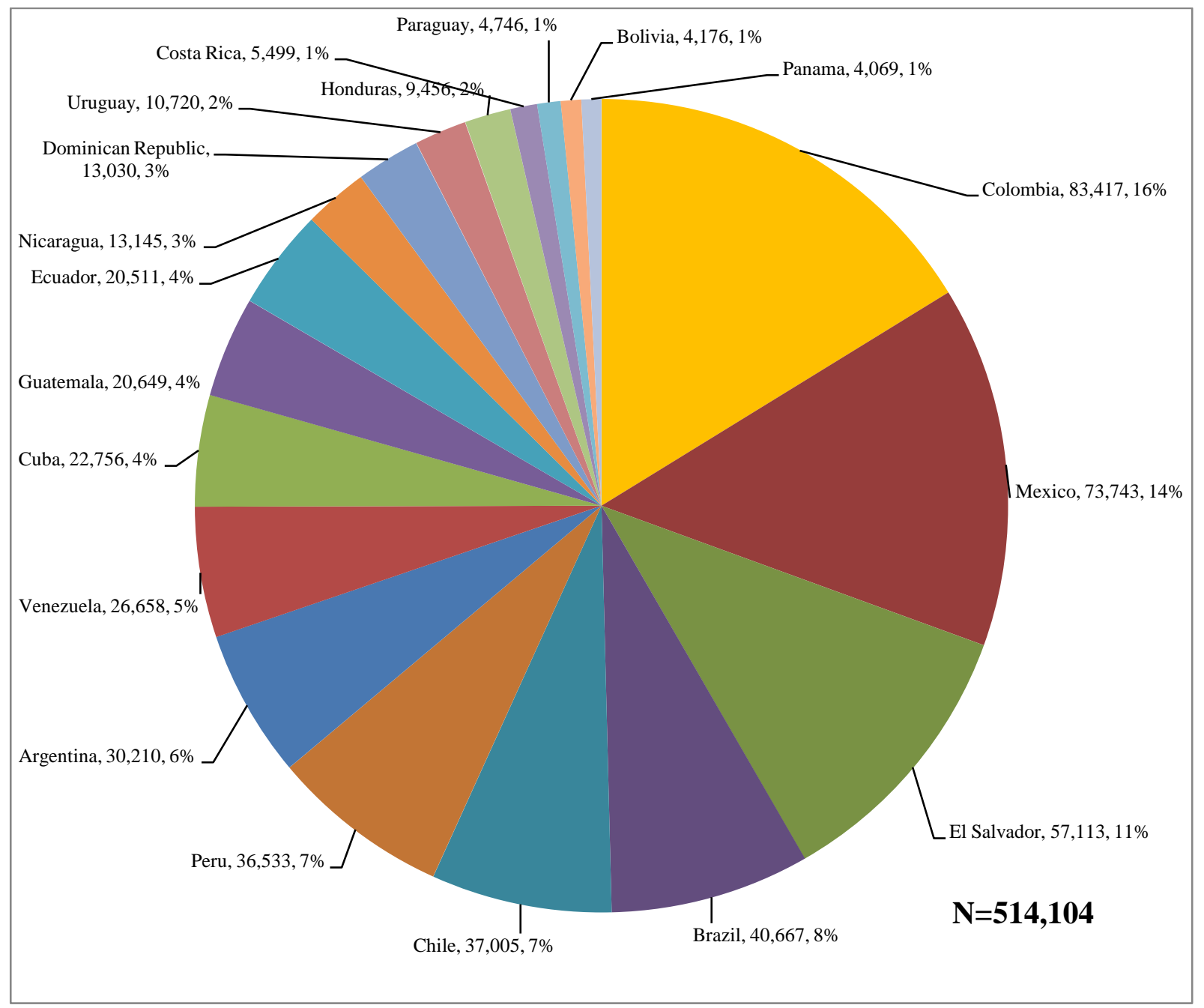

Sources: (1) 1965-1979: Table 14, Immigration Statistics, Employment, and Immigration Canada, (2) 1980-2015: Permanent Residents - Ad Hoc IRCC (Specialized Datasets)- Admissions of Permanent Residents by Country of Citizenship (Q1-Q2 2016 ranking), 1980 - Q2 2016. Note: some figures may be rounded.

Compared to the U.S., immigrant inflows from Latin America are significantly smaller but are more representative of the rich national diversity present in the region ${ }^{3}$ (see Chart 2). According to yearly immigration statistics by source countries of citizenship, between 1965 and 2015, five countries accounted for more than half (56\%) of the immigrant intake from the major 19 countries of the region: Colombia (16\%, 83.4 thousand), Mexico (14\%, 73.7 thousand), El Salvador (11\%, 57.1 thousand), Brazil (8\%, 40.7 thousand) and Chile (7\%, 37.0 thousand). All sub-regions of the continent are fairly represented in this immigration intake.

\footnotetext{
3 According to the U.S. Bureau of the Census, between 1965 and 2019, about 24 million individuals were admitted from Latin American countries. Slightly over half (51\%) of them were Mexican citizens while the remaining $49 \%$ came from other countries. In Canada (with a quarter of a million individuals), the corresponding percentages were $14 \%$ and $86 \%$, respectively. The percentage share of Mexicans in the immigration intake of Latin America in Canada, however, has been rising over time. Approximately $10 \%$ of those entering Canada before 1970 were Mexican citizens. This figure jumped to $26 \%$ for those admitted between 2000 and 2015. Source: U.S. Census Bureau, Current Population Survey, Annual Social and Economic Supplement, 2019, Internet release, April 2020.
} 
Chart 3: Admissions of Permanent Residents by Country of Citizenship and Years, Selected Latin American Countries, 1965-2015

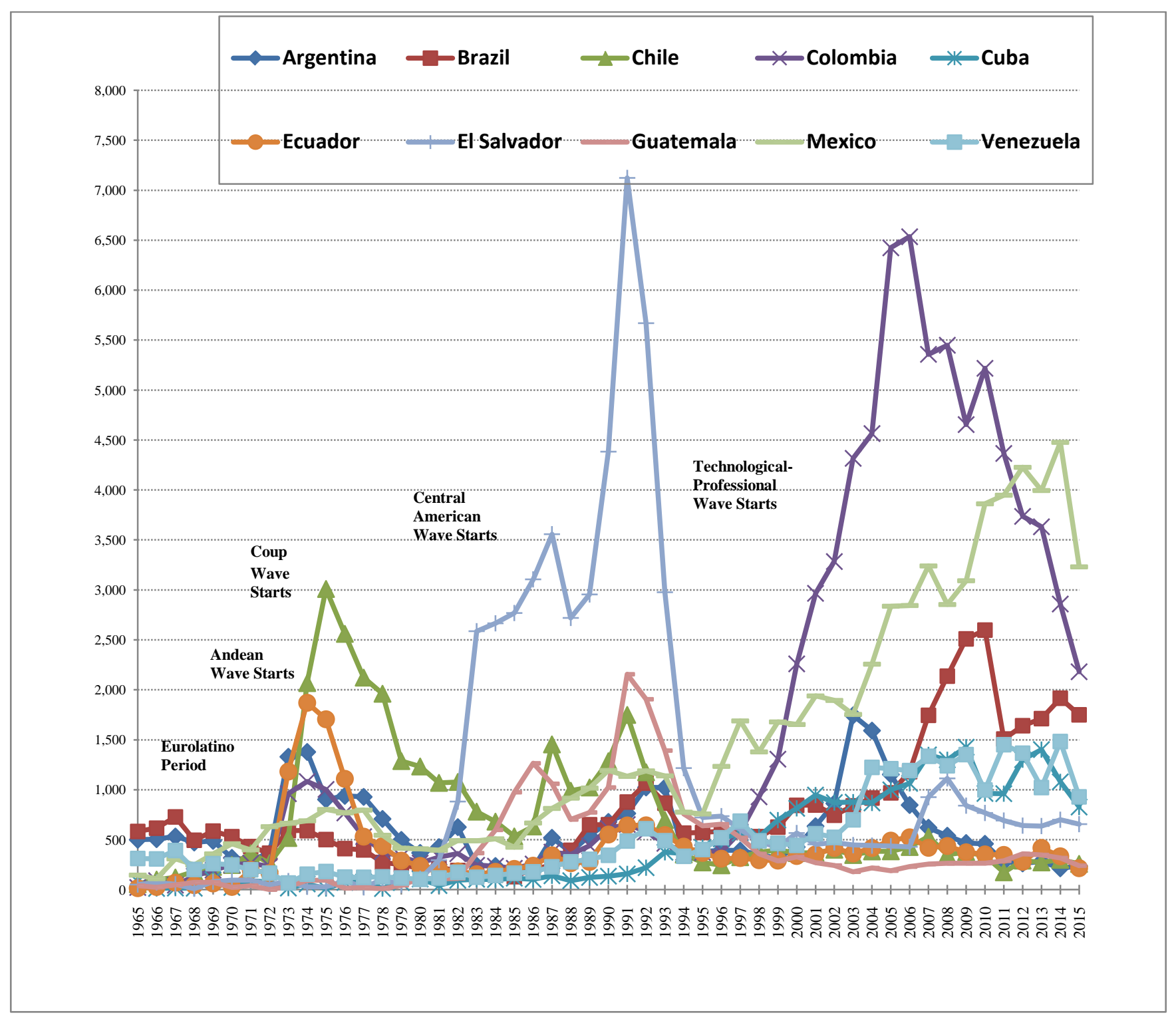

Sources: (1) 1965-1979: Table 14, Immigration Statistics, Employment, and Immigration Canada, (2) 1980-2015: Permanent Residents - Ad Hoc IRCC (Specialized Datasets)- Admissions of Permanent Residents by Country of Citizenship (Q1-Q2 2016 ranking), 1980 - Q2 2016. Note: some figures may be rounded.

The time series diagram shown in Chart 3 visualizes the various "peaks" and "valleys" of Latin American immigration into Canada during 1965 and 2015 . The "major" peaks correspond to Colombian, Mexican, and Salvadorean admissions to Canada, countries representative of the technological-professional and Central American waves respectively. Minor peaks in the earlier periods are observable for Chilean and Ecuadorian citizens, countries representative of the earlier Coup and Andean waves, The period 1965-1972 appears "flatter" than other periods though the admissions of citizens from Brazil, Argentina, and Mexico are observable in the chart.

\footnotetext{
${ }^{4}$ Permanent resident admissions during $1965-2015$ by year for the 19 countries of citizenship are presented in detail in detail in tables A-1 and A-2 of the Annex.
} 


\subsection{Historical Moments of Latino Immigration to Canada}

\subsection{Eurolatino ${ }^{5}$ or Lead Wave (Momentum: Post WWII Years-1972): The European Connection}

The early 1965-72 period is characterized by the visible presence of Eurolatino immigrants ${ }^{6}$. They came from the most industrially advanced countries of the region such as Argentina, Brazil, Mexico, and Venezuela. Paraguayan immigrants also moved to Canada more frequently during this period. Most Eurolatinos had strong ethnic links to Europe (countries such as Spain, Portugal, Italy, Germany, and the Netherlands), Jewish communities, and the Spanish and Poruguese- speaking colonies in Africa and Asia. Latin America may have been a temporary residence before heading towards Canada or the U.S. In the early 60s, the Immigration Act of 1952 was amended. This expanded the spectrum of manpower recruitment and facilitated a quicker sponsorship of relatives for individuals already present in Canada. Later, in 1967, Canada also amended its immigration policy introducing a point system for immigrant selection. This further development enhanced the arrival of thousands of skilled and non-skilled workers from the metropolitan areas of North, Central, and South America.

Chart 4: Admissions of Permanent Residents by Country of Citizenship and Years: Argentina, Brazil, Mexico and Paraguay, Canada, 1965-1972

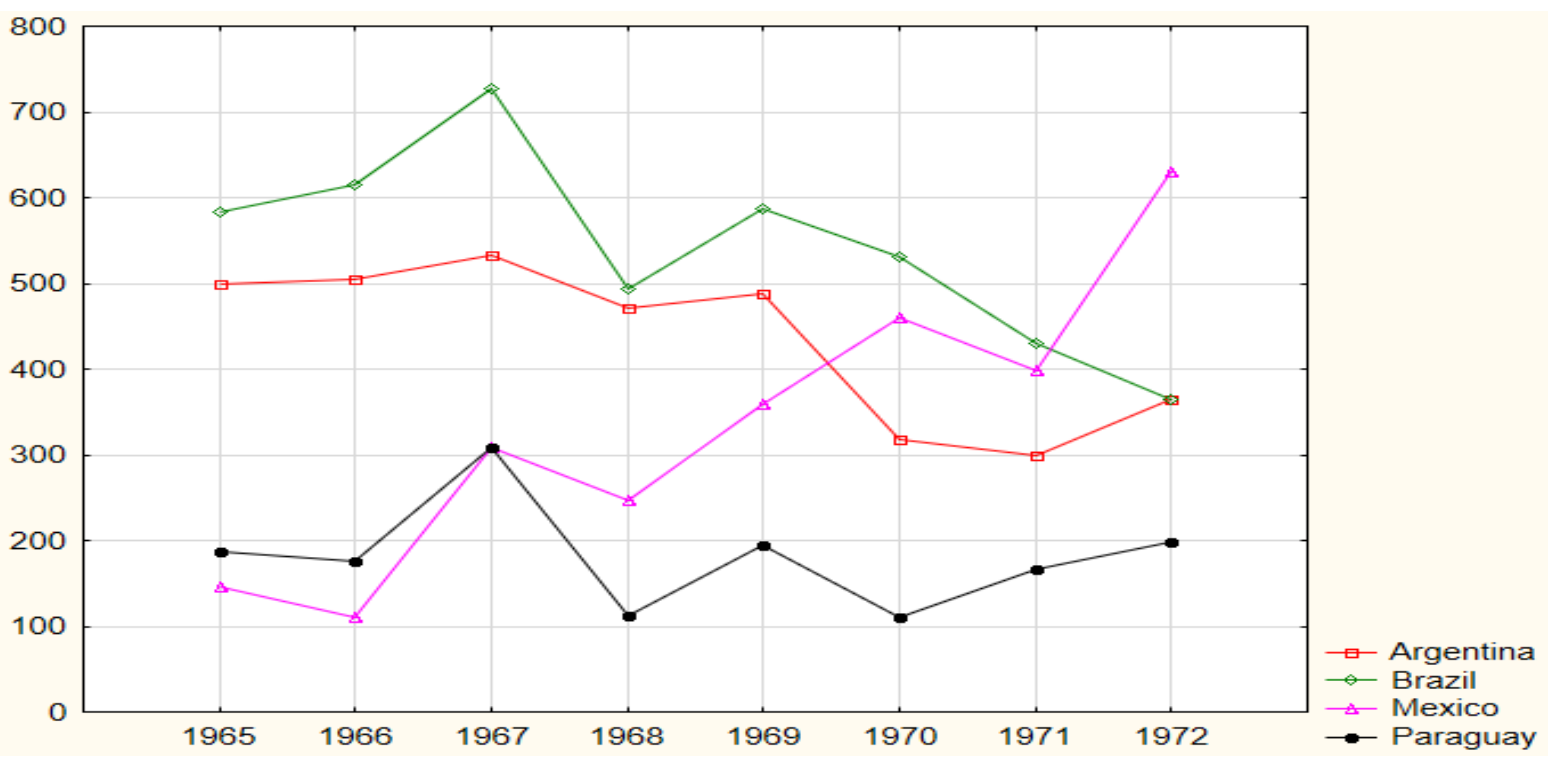

5 Clarke and Anderson (1973) and Anderson (1981) describe well the basic characteristics of Eurolatino immigrants of the period.

${ }^{6}$ It should be noted that in the pre-war years, South and Central American immigrants were placed in the third priority category of the immigration system. 


\subsection{Andean Wave (Momentum: 1973-1975): Amnesty Seekers}

The 1973 Immigration amnesty triggered an inflow of Latinos who wanted to regularize their immigration status in Canada. This unprecedented disposition allowed visitors to apply for landed status after arrival affecting all visitors entering Canada before 1972. Conservative estimates (Robinson, 1983) indicated that there were approximately 200,000 "illegals" living in Canada at the time, 38\% of them residing in Metropolitan Toronto. Although thousands of Ecuadorian citizens applied and were accepted as permanent residents, Colombians and Peruvians also benefited from this amnesty (Bonavia, 1977). Ecuadorian admissions display a notable "peak" around 1973 although smaller ones are also visible after this particular time point. The Andean wave comprised of a large human contingent comprising both skilled and unskilled laborers. Chronologically, the social developments of the 1973 Amnesty coincided with the aftermath of a bloody coup in Chile in 1973 which triggered the subsequent Coup wave.

Chart 5: Admissions of Permanent Residents by Country of Citizenship and Years: Ecuador, Canada, 1965-2015

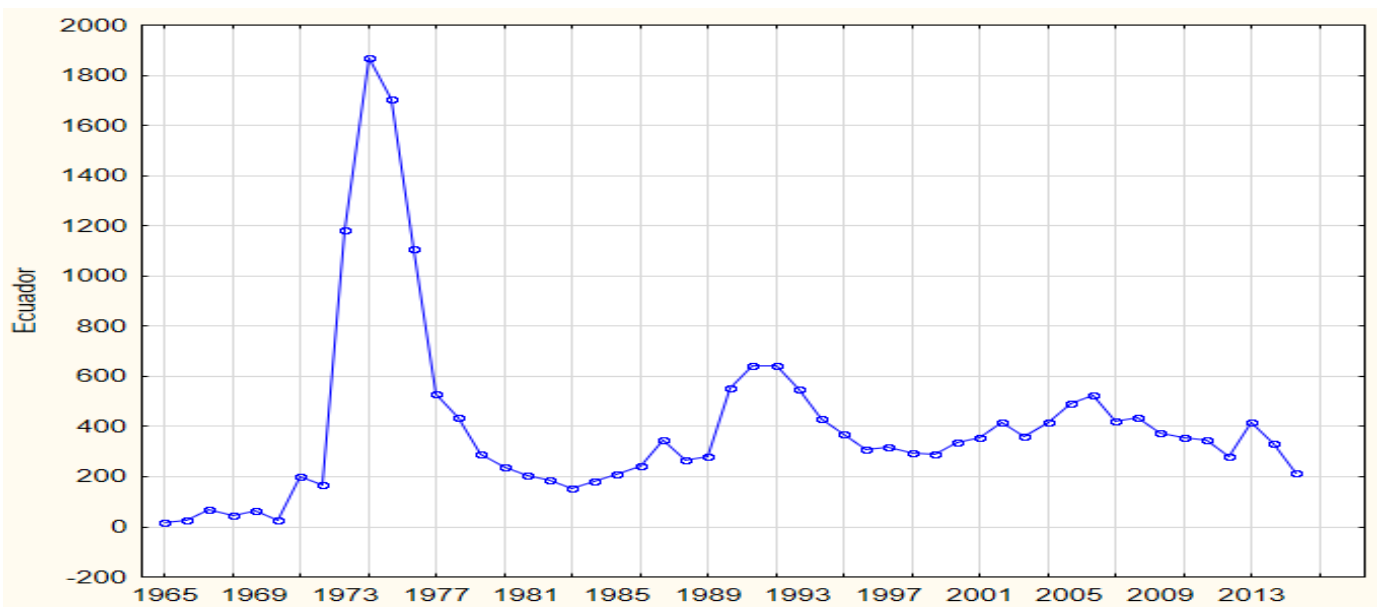

\subsection{Coup Wave (Momentum: 1973-1985): Escaping Military Juntas}

Political developments in Chile as well in other countries of the Southern cone of Latin America are the major drivers of this immigrant wave. Under United Nations High Commissioner on Refugees (UNHCR) auspices, approximately 8,000 Chilean refugees and an additional 2,000 foreigners registered with church-run camps in Santiago were accepted as permanent residents in Canada ${ }^{7}$. Like Chileans, Argentinian and Uruguayan citizens fleeing military regimes also entered Canada during this period. The human contingent of the Coup wave was initially biased towards professionals and intellectuals but later was followed by both skilled and unskilled workers. In 1976, a new immigration act was passed by the Canadian Parliament. The "peak" of Chilean admissions occurs in 1975 (the year when the so-called "Operacion Colombo" was undertaken by the Chilean secret police to target political dissidents). Chileans became the most numerous Latino group in Canada in the 1980s. In the case of Argentina, three migratory peaks are noticeable: 1974 (Lanusse's military

\footnotetext{
7 Dealing with the integration of this refugee movement presented both expected and unexpected short, medium and long term integration challenges for Canada and community members (see for instance the work undertaken by Hanff (1979), Duran (1980), Basok (1983), Landolt and Goldring (2010), Peddie (2018) and Raska (2020)).
} 
junta), 1992 (Menen's presidency), and 2003 (Kirchner administration).

Chart 6: Admissions of Permanent Residents by Country of Citizenship and Years: Chile, Argentina, and Uruguay, Canada, 1965-2015

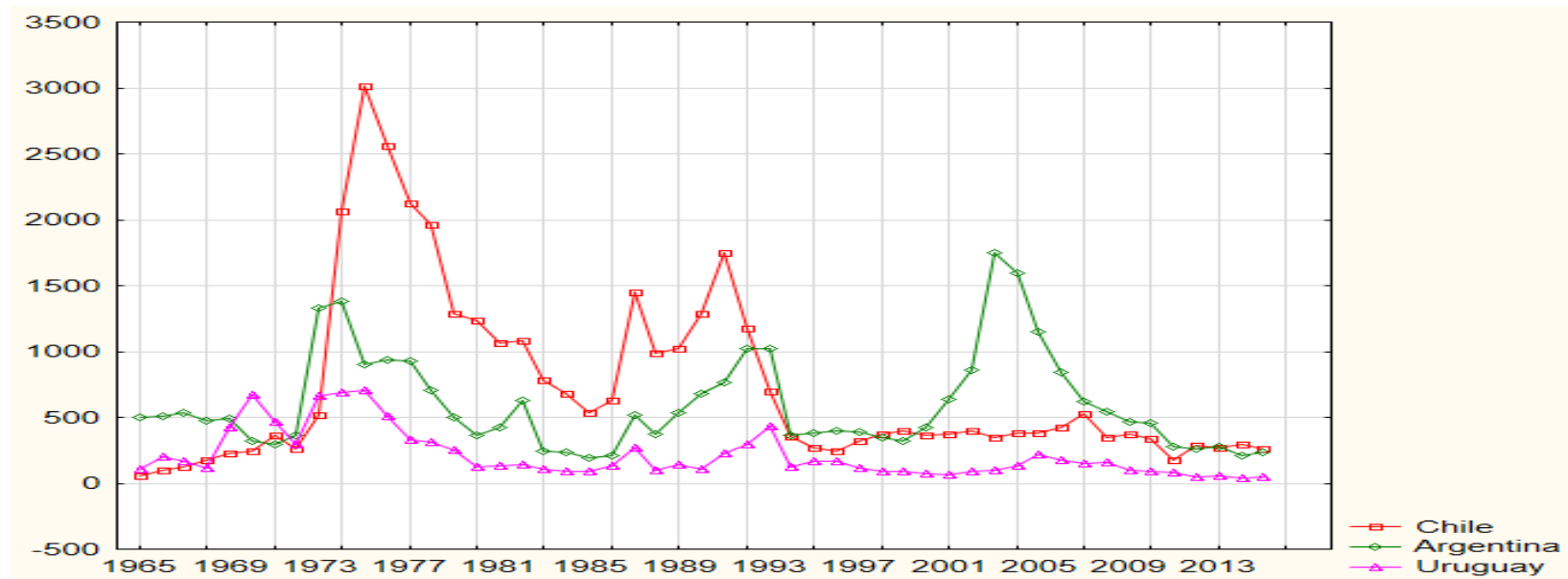

\subsection{Central American Wave (Momentum: 1983-1995): Fleeing Civil Wars}

The political situation and later civil war in Central America in the mid-80s were major antecedents of this migratory movement. Between 1983 and 1995, Salvadoreans, Guatemalans, Nicaraguans, and Hondurans found a new home in Canada ${ }^{8}$. The crises mostly affected the urban poor, the rural middle class, and the peasantry of Central American countries. Canadian resettlement efforts were concentrated on refugees who were unlikely to be repatriated and those who had a close connection to the UNHCR or Canadian churches.

Most Salvadorean refugee admissions were governmental or privately funded, but many also arrived as familyclass immigrants. The Central American wave reached its peak in 1991 with the arrival of about 7,000 permanent residents from El Salvador. To a minor extent, admissions from Guatemala, Nicaragua, and Honduras "mimicked" Salvadorean admissions to Canada.

Chart 7: Admissions of Permanent Residents by Country of Citizenship and Years: El Salvador, Guatemala, Honduras and Nicaragua, Canada, 1965-2015

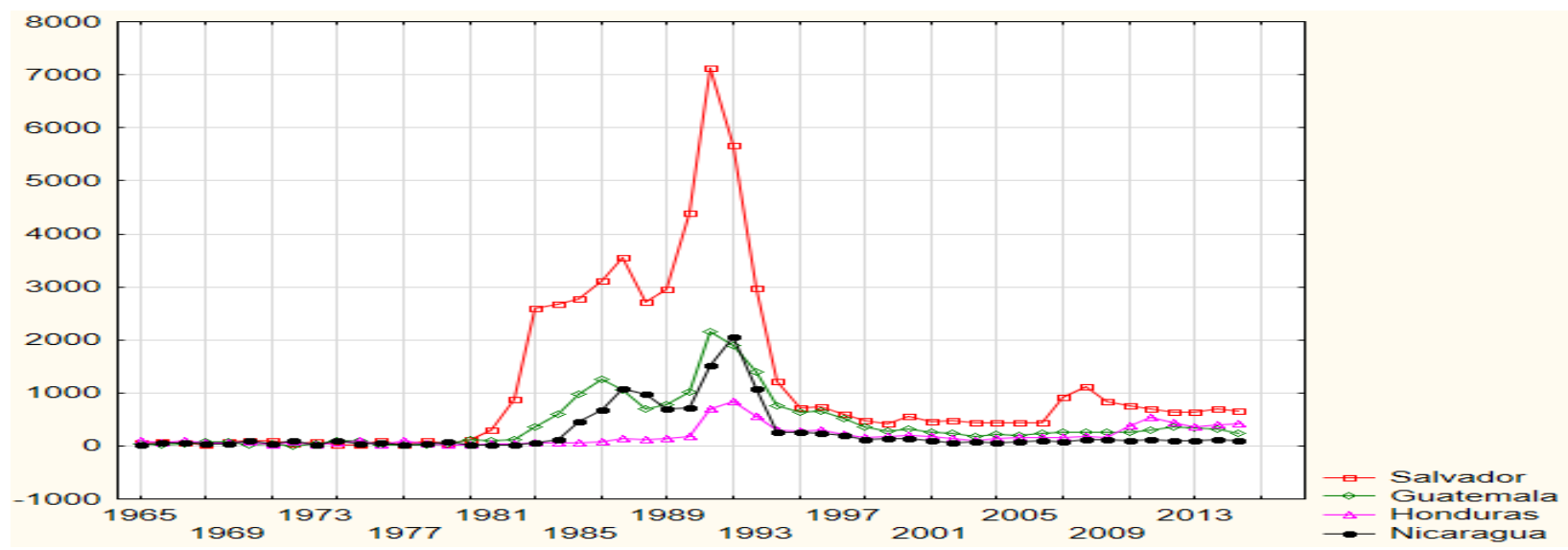

\footnotetext{
8 Research undertaken by Ferris (1987) and Kowalchuk (1999) provide good overviews of the socio-demographic characteristics of Central American wave members at the time.
} 


\subsection{Technological-Professional Wave (Momentum: 1995-2012): Two Streams In One}

This recent wave was triggered around the mid-1990s. It comprises a mixed group of individuals ranging from professional and highly skilled workers drawn from the STEM ${ }^{9}$ industries to individuals of lower educational profiles who have regularized their status after being initially admitted as visitors, temporary workers, students, and/or refugee claimants ${ }^{10}$. Citizens from Colombia, Mexico, Brazil, Cuba, and Venezuela are the most representative members of the wave. Economic instability, health crises, rising social conflict, and a deep socio-economic restructuring are said to be the major push-related factors associated with this particular wave (ECLAC, 2019). The heterogeneity both in terms of the social-demographic background mix and pathways or trajectories towards permanent residency (e.g. from a "precarious" status to a "non -precarious" one) ${ }^{11}$ suggests this particular wave has a dual character whereby two separate immigrant streams appear to coalesce in time. The peak of the technological-professional wave occurred in 2006 when about 6.5 thousand Colombians were admitted as permanent residents to Canada (President Uribe's administration) ${ }^{12}$. The Mexican peak of the wave occurred more recently in 2014 when about 4.5 thousand were admitted. Brazilian, Venezuelan, and Cuban immigration also have kept pace with that of Colombian and Mexican admissions ${ }^{\mathbf{1 3}}$.

Chart 8: Admissions of Permanent Residents by Country of Citizenship and Years: Colombia, Mexico, Brazil, Venezuela and Cuba, Canada, 1965-2015

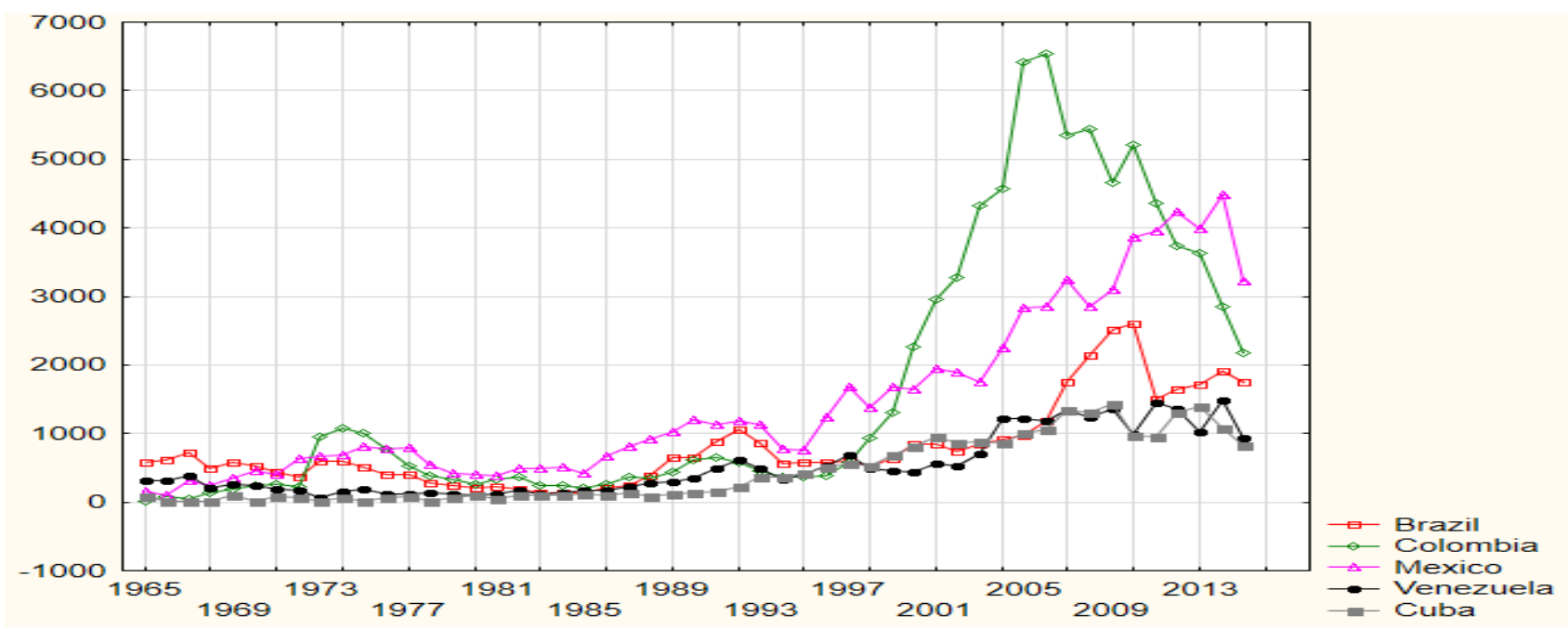

${ }^{9}$ STEM refers to the Science, Technology, Engineering and Mathematics sectors.

10 Some Canadian scholars suggest that many immigrants of the fifth wave who later regularize their status (precarious to non-precarious) may be part of the non-permanent resident pool of previous years (Goldring and Landolt, 2021). The case of Mexican agricultural workers has been, perhaps, one of the most studied (McLauglin and Hennebry, 2013; Basok et. al 2014, Villegas 2020). At the time of the 2016 Census there were 25,415 individuals reporting different Latin American ethnic origins who were counted as non-permanent residents (13,345 males and 12,065 females). More than a third of them (34\%) of them were Mexicans, 19\% Brazilian and 13\% Colombian. In terms of educational profiles, $44 \%$ of them had attained secondary education or less, $40 \%$ university education and $16 \%$ some post-secondary education or college level. See table A-3 in the appendix for more details.

${ }^{11}$ Under the differential inclusion theoretical framework and using samples of Latino and Caribbean workers living in Toronto, Goldring and Landolt (2021) have carried out interesting work in this regard .

12 According to Alcala et. al. (2008), the root causes of Colombian migration to Canada are the violence and poverty affecting a significant segment of the population. Humanez Blanquicett (2019) ties these causes to the various "waves" of Colombians arriving to the city of Montreal in the last decades. Although early Colombian immigration to Canada comprised many economic and family class admissions, it also had a significant number of refugee class entrants which faced severe integration challenges (Veronis, 2010). In 2004, Colombia became the primary source of refugee claimants in Canada.

${ }^{13}$ Brazilian immigration to Canada has a significant number of individuals arriving as professionals and highly skilled economic class entrants Vendramin (2013) found that many of these Brazilian workers, despite being highly educated, tend to be concentrated in occupations related to the "secondary" occupational sector of low-paid jobs. Occupational challenges are greater for Colombians, Venezuelan and Cuban immigrants which have larger contingents of refugee class entrants. Between 2015 to 2019, there was an extraordinary $467 \%$ percent increase in

Venezuelan asylum claimants in Canada (GC, 2020). 


\subsection{Sustaining Wave (Intermittent, 1965-2015): Buttressing Role}

During 1965-2015, Latin American immigration to Canada was also sustained by inflows drawn from source countries not necessarily representative of the five larger waves. Citizens from countries such as Peru, Bolivia, Costa Rica, the Dominican Republic, Panama, and Paraguay have entered Canada at different points in larger and/or smaller volumes. Their inflows to Canada changed according to particular socio-economic conditions in their homelands and also as a consequence of domestic developments occurring in terms of immigration policy priorities. The most representative case of a sustaining wave is the larger Peruvian immigration to Canada. Two migratory peaks are observed for Peruvian admissions to Canada: 1991-1993 (aftermath of the "Shining Path" insurrection) and 2003 (period of economic uncertainty during the Toledo presidency).

Chart 9: Admissions of Permanent Residents by Country of Citizenship and Years: Peru, Bolivia, Costa Rica (CR), Dominican Republic (DR), Panama and Paraguay, Canada, 1965-2015

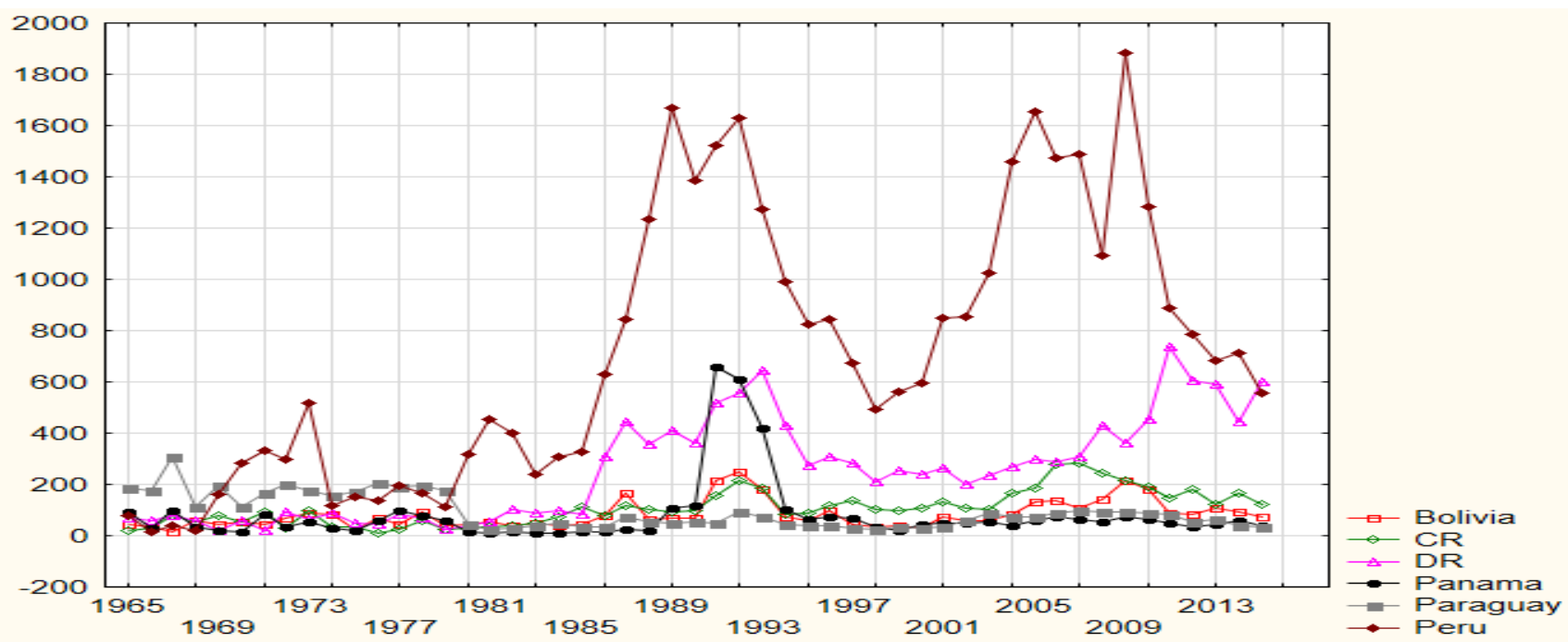

\subsection{Census Data Explorations: The 1981-2016 period}

Data from the 2016 Canadian Census allows for an indirect examination of Latin American immigrant waves to Canada using a retrospective approach (e.g. asking foreign-born census respondents to report details on their admission to Canada) ${ }^{14}$. Using special tables from the 2016 Canadian Census, the author examined several sociodemographic and occupational characteristics of members of Latin American ethnic immigrant inflows as they appeared at census time. Ethnic immigrant inflows are defined in the 2016 census as population movements where the ethnic origin of immigrants is identified. In the analysis, 19 ethnic origins of immigrants in the 2016 census were matched to those of the countries of citizenship of immigrants which are available in the annual immigration statistics $^{15}$. The time frame of observation of ethnic immigrant inflows, however, is restricted to immigrant

${ }^{14}$ In the 2016 Census, characteristics such as the ethnic ancestry and the year of obtaining the landed immigrant status were systematically linked to their three admission class categories (economic, family and refugee).

15 About 310.5 thousand immigrants of 19 identifiable Latin American ethnic origins (i.e. matching those of IRCCs citizenship markers) were selected for analysis. The counts in thousands were as follows: Colombian (63.0), Mexican (54.4), Salvadorean (33.8), Peruvian (22.0)

Brazilian(15.4), Cuban (15.0), Venezuelan (14.5), Chilean (12.0), Guatemalan (11.8), Dominican (9.1), Ecuadorian (8.0), Nicaraguan (6.9),

Argentinian (6.8), Honduran (5.3), Costa Rican (2.4), Panamanian (1.7), Uruguayan (1.6), Paraguayan (1.1) and Bolivian (1.0). Generic ethnic 
admissions occurring during the 1981-2016 period. The following sections present selected findings of these data explorations.

\subsection{Strong Presence of Women in Ethnic Immigrant Inflows}

According to the 2016 Census, women were slightly overrepresented in the Latin American ethnic inflows to Canada between 1981 and 2016. More than half of these inflows (56\%) corresponded to female immigrants while only 44\% corresponded to male immigrants. About $60 \%$ or more of inflows from ethnic origins related to countries such as Peru, Ecuador, Panama, and Venezuela comprised women. About equal proportions of males and females in ethnic inflows were found among Uruguayan, Guatemalan, Paraguayan, and Argentinian immigrants (between 50\%-54 \% male).

\subsection{Ontario and Quebec, the Most Preferred provincial Residences for all Wave Members Except for Paraguayans}

In terms of residential preferences (see Table 1), regardless of wave origins, Latin American ethnic immigrant inflows tend to gravitate towards the Ontario province and to Metropolitan Toronto in particular (44\% and 30\% respectively). Four out of five Ecuadorians resided in Ontario in 2016 (80\%). The province of Quebec was particularly attractive for Peruvians and Hondurans (47\% and 41\% respectively). Two in ten Latinos resided in the provinces of Alberta and British Columbia. A clear outlier of the census statistics is Paraguayan immigration; close to half of whom (48\%) resided in the province of Manitoba in 2016. Previous studies suggest that these movements are an "offshoot" of the Eurolatino wave started in the 1950s and partly linked to the movement of European families to rural areas of Manitoba as a consequence of family reunification and the expansion of the Mennonite and other Protestant faiths (Kehler, 2019).

Table 1: Provincial and Metropolitan Residences of Ethnic Immigrant Inflows* from Latin America to Canada, 1981-2016

\begin{tabular}{|c|c|c|c|c|c|c|c|c|c|c|}
\hline Ethnic Origins & Atlantic & Quebec & $\begin{array}{r}\text { Montreal } \\
\text { CMA }\end{array}$ & Ontario & $\begin{array}{r}\text { Toronto } \\
\text { CMA }\end{array}$ & Manitoba & Saskatchewan & Alberta & B.C. & $\begin{array}{r}\text { Vancouver } \\
\text { CMA }\end{array}$ \\
\hline Argentinian (p) & $1 \%$ & $24 \%$ & $21 \%$ & $55 \%$ & $41 \%$ & $2 \%$ & $1 \%$ & $7 \%$ & $10 \%$ & $7 \%$ \\
\hline Bolivian (s) & $2 \%$ & $34 \%$ & $26 \%$ & $37 \%$ & $26 \%$ & $6 \%$ & $1 \%$ & $12 \%$ & $7 \%$ & $4 \%$ \\
\hline Brazilian (t) & $1 \%$ & $23 \%$ & $17 \%$ & $50 \%$ & $35 \%$ & $2 \%$ & $1 \%$ & $8 \%$ & $15 \%$ & $11 \%$ \\
\hline Chilean (p) & $1 \%$ & $31 \%$ & $27 \%$ & $32 \%$ & $23 \%$ & $3 \%$ & $2 \%$ & $18 \%$ & $13 \%$ & $8 \%$ \\
\hline Colombian (t) & $1 \%$ & $35 \%$ & $24 \%$ & $42 \%$ & $26 \%$ & $1 \%$ & $1 \%$ & $13 \%$ & $6 \%$ & $5 \%$ \\
\hline Cuban (t) & $2 \%$ & $34 \%$ & $27 \%$ & $50 \%$ & $32 \%$ & $1 \%$ & $1 \%$ & $7 \%$ & $5 \%$ & $3 \%$ \\
\hline Costa Rican (s) & $1 \%$ & $34 \%$ & $27 \%$ & $50 \%$ & $32 \%$ & $2 \%$ & $8 \%$ & $1 \%$ & $4 \%$ & $1 \%$ \\
\hline Dominican (s) & $1 \%$ & $21 \%$ & $17 \%$ & $50 \%$ & $32 \%$ & $1 \%$ & $1 \%$ & $4 \%$ & $3 \%$ & $2 \%$ \\
\hline Ecuadorian (a) & $1 \%$ & $11 \%$ & $9 \%$ & $80 \%$ & $71 \%$ & $0 \%$ & $0 \%$ & $4 \%$ & $4 \%$ & $3 \%$ \\
\hline Guatemalan (c) & $1 \%$ & $39 \%$ & $33 \%$ & $38 \%$ & $23 \%$ & $2 \%$ & $1 \%$ & $9 \%$ & $10 \%$ & $8 \%$ \\
\hline Honduran (c) & $1 \%$ & $41 \%$ & $37 \%$ & $32 \%$ & $16 \%$ & $5 \%$ & $1 \%$ & $7 \%$ & $14 \%$ & $11 \%$ \\
\hline Mexican (t) & $1 \%$ & $21 \%$ & $16 \%$ & $34 \%$ & $15 \%$ & $7 \%$ & $2 \%$ & $17 \%$ & $18 \%$ & $12 \%$ \\
\hline Nicaraguan (c) & $1 \%$ & $20 \%$ & $16 \%$ & $52 \%$ & $27 \%$ & $3 \%$ & $1 \%$ & $12 \%$ & $11 \%$ & $8 \%$ \\
\hline Panamanian (s) & $1 \%$ & $31 \%$ & $28 \%$ & $53 \%$ & $38 \%$ & $1 \%$ & $0 \%$ & $7 \%$ & $7 \%$ & $4 \%$ \\
\hline Paraguayan (s) & $0 \%$ & $8 \%$ & $6 \%$ & $14 \%$ & $7 \%$ & $48 \%$ & $1 \%$ & $8 \%$ & $21 \%$ & $6 \%$ \\
\hline Peruvian (s) & $1 \%$ & $47 \%$ & $41 \%$ & $35 \%$ & $25 \%$ & $1 \%$ & $1 \%$ & $7 \%$ & $9 \%$ & $7 \%$ \\
\hline Salvadorean (c) & $0 \%$ & $29 \%$ & $26 \%$ & $42 \%$ & $23 \%$ & $4 \%$ & $1 \%$ & $13 \%$ & $10 \%$ & $8 \%$ \\
\hline Uruguayan (p) & $0 \%$ & $26 \%$ & $22 \%$ & $62 \%$ & $51 \%$ & $1 \%$ & $1 \%$ & $5 \%$ & $6 \%$ & $4 \%$ \\
\hline Venezuelan (t) & $1 \%$ & $28 \%$ & $25 \%$ & $45 \%$ & $31 \%$ & $1 \%$ & $0 \%$ & $18 \%$ & $7 \%$ & $6 \%$ \\
\hline All origins & $1 \%$ & $30 \%$ & $25 \%$ & $44 \%$ & $30 \%$ & $5 \%$ & $1 \%$ & $10 \%$ & $10 \%$ & $6 \%$ \\
\hline
\end{tabular}

* Highlighted: percentages of 40\% plus. Symbols: (a) =Andean wave linked, (p)=Coup wave linked, (c) =Central American wave linked, (t) Technological-Professional wave linked, (s) =Sustaining wave linked, Source: Custom Tabulation EO2680, 2016 Census of Canada 


\subsection{Central American and Coup Wave Members had the longest stay in Canada, Technological- Professional Wave Members The Shortest}

The cohort arrival composition of the Latino ethnic immigrant inflows captured by the 2016 Census is presented in Chart 3. About one in three immigrants had arrived in the period before 1981 (35\%) with the highest proportions observable among Salvadoreans, Nicaraguans, and Chileans (at least 41\%). These are ethnic origins representative of the Central American and Coup waves identified using immigration statistics. On the other side of the arrival cohort spectrum, close to $30 \%$ of immigrants had arrived between 2001-2016 with Colombians, Venezuelans, Cuban, Brazilian, and Mexicans as those with the highest proportions of the more recent arrivals to Canada. These immigrants are representative of the recent "technological-professional" fifth immigrant wave described by Canadian scholars.

Chart 10: Arrival Cohorts of Ethnic Immigrant Inflows* from Latin America to Canada, 2016 Census of Canada, 1981-2016

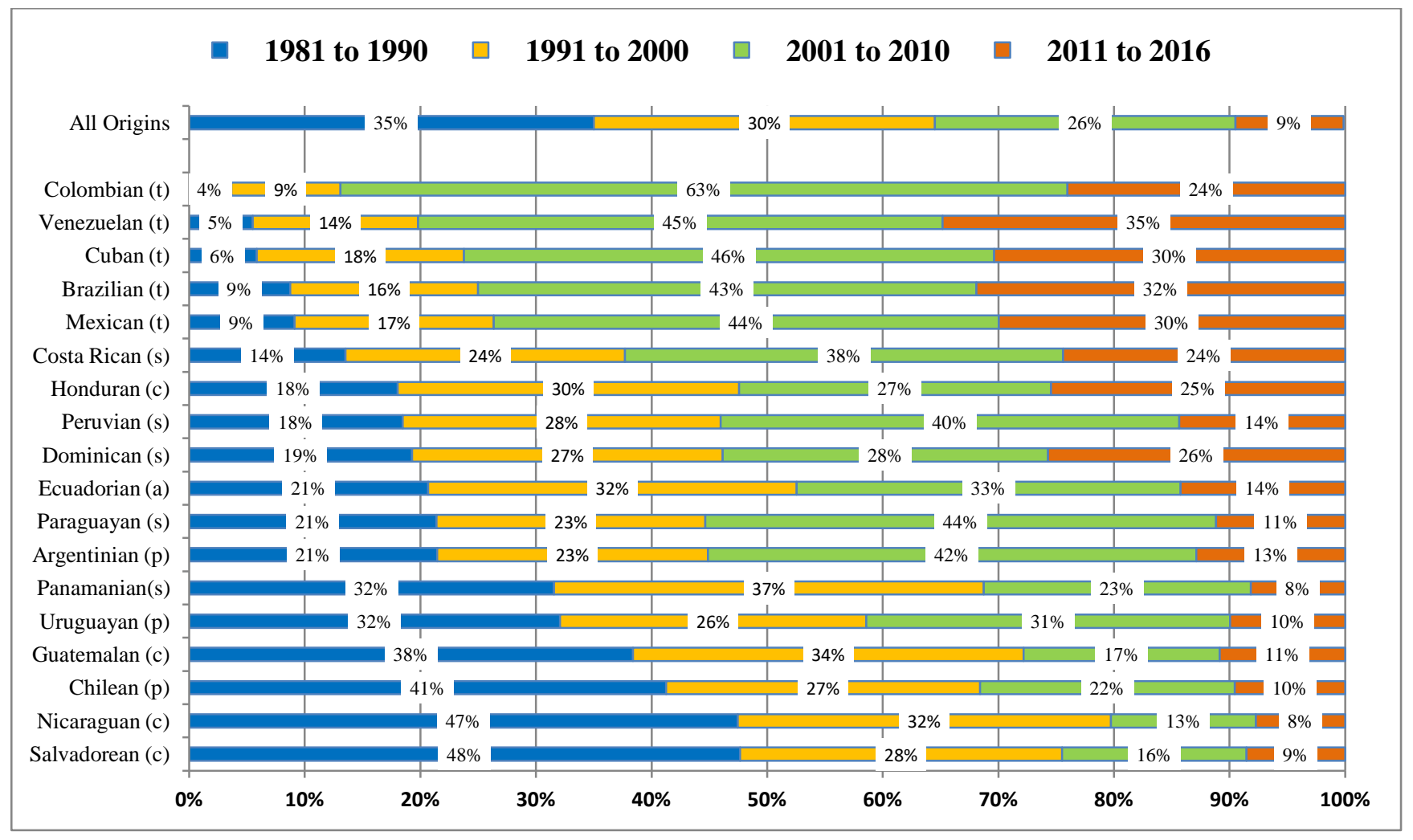

*Symbols: (a) =Andean wave linked, (p)=Coup wave linked, (c)=Central American wave linked, $(\mathrm{t})=$ Technological-Professional wave linked, $(\mathrm{s})=$ Sustaining wave linked. Source: Custom Tabulation EO2680, 2016 Census of Canada

\subsection{Family Class Admissions Dominant followed by Economic Ones, One in Four Latino Immigrants Arrived As Refugees During 1981-2016}

Information on the immigrant intake class composition of Latin American immigrants is useful as it provides an indirect account of the human capital brought by immigrants (e.g. via the point system selection). Chart 4 displays these characteristics for all Latin American immigrants from the major 19 countries admitted to Canada between 1981 and 2016. Overall, 40\% of all immigrant admissions corresponded to family entrants, 
$36 \%$ to economic ones, and $24 \%$ to refugee ones. Looking in more detail at the national breakdown, the 2016 census figures reveal some degree of polarization occurring in terms of the immigrant class composition of inflows. While Central American inflows (e.g. Central American wave) such as the Salvadorean, Nicaraguan, Guatemalan, and Colombians had a higher predominance of refugee entrants (50\% or more). In other inflows, we observe a higher presence of either economic class admissions (e.g. Venezuelan, Argentinian, and Brazilians) or family class entrants (e.g. Ecuadorians and Cuban). The breakdown for the Colombian ancestry group revealed that close to half (48\%) were admitted as refugees, $36 \%$ as economic class, and $16 \%$ as family class immigrants. With regards to those with Mexican ancestry, the most frequent type of admission was as economic class immigrants (42\%) closely followed by family (41\%) and refugee class (18\%).

Chart 11: Immigrant Intake Class Composition of Ethnic Immigrant Inflows* from Latin America to Canada, 1981-2016

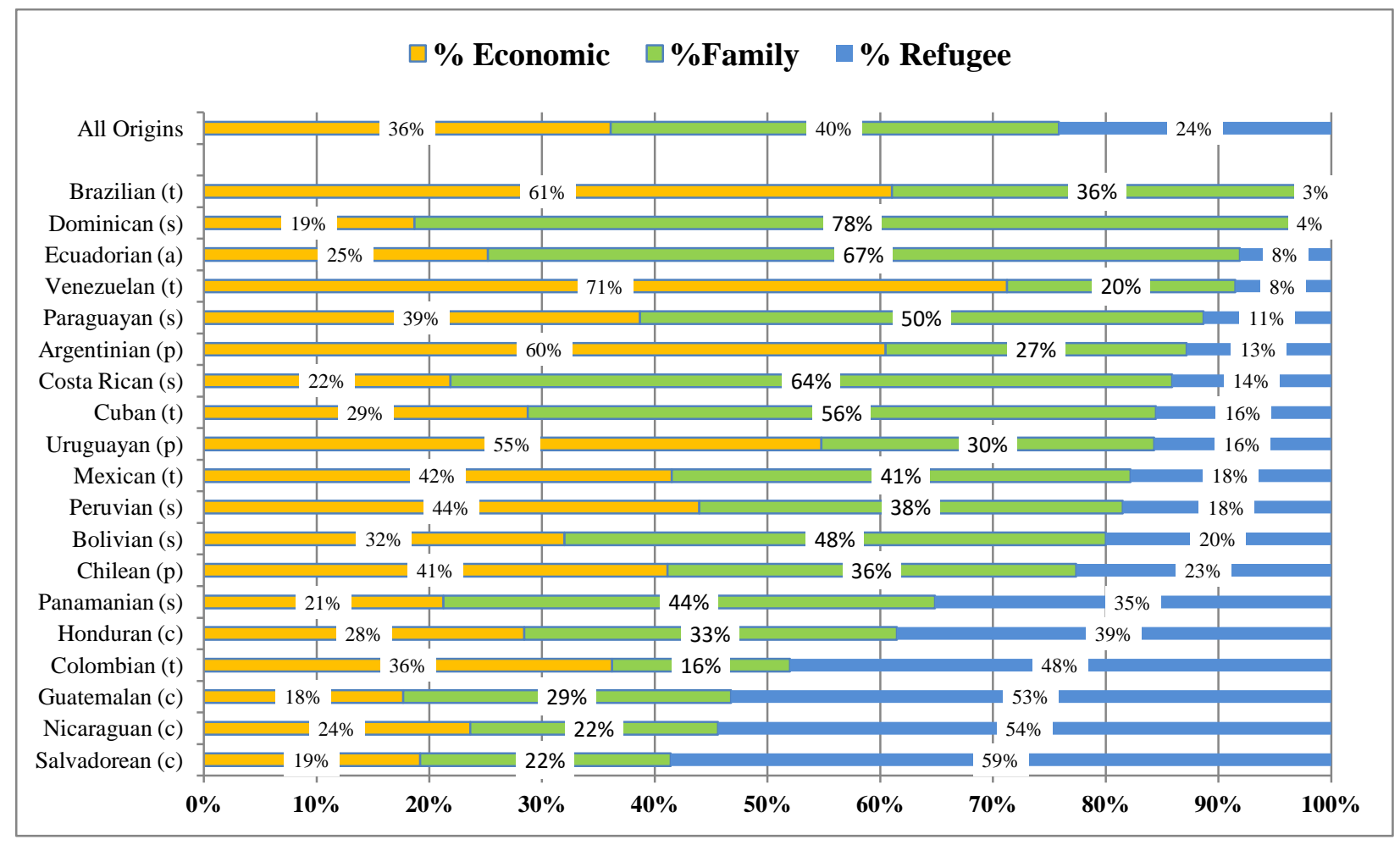

* Symbols (a) =Andean wave linked, (p)=Coup wave linked, (c)= Central American wave linked, (t) =Technological-Professional wave linked, (s) =Sustaining wave linked. Source: Custom Tabulation EO2680, 2016 Census of Canada

\subsection{Technological-Professional and Coup Wave Female Members the Most University Educated, Central American Wave Male Members The Least}

The concept of human capital attainment comprises all outputs closely linked to knowledge, skills, education, and abilities. This particular exploration using 2016 Census data concentrated its attention on the highest level of education attained by ethnicity in inflow members of the working Latino population of Canada. It revealed significant differences in terms of human capital between the Technological-Professional wave and Coup wave members and Central American ones. The former groups of immigrants ranked higher than the latter group both among males and females. About 34\% of Latino women had attained university education compared to 
27\% among men. Males were overrepresented in the high school or less educational category (38\% to 29\%). A closer inspection of the figures by ethnic origins suggests that $40 \%$ or more of female members linked to the Technological-Professional Waves (Venezuelan, Brazilian, Colombian, and Argentinian) had attained university education by 2016. These percentages were lower for their male counterparts. On the other side of the educational spectrum, half of Salvadorean, Honduran, and Paraguayan male workers had only attained high school education or less. Trades and Post Secondary Levels were observable for Uruguayan and Chilean males (41\% and 40\% respectively) as well Nicaraguan females (51\%)

Chart 12: Educational Composition of Ethnic Immigrant Inflows* from Latin America to Canada, Employed Males aged 25-54, 1981-2016

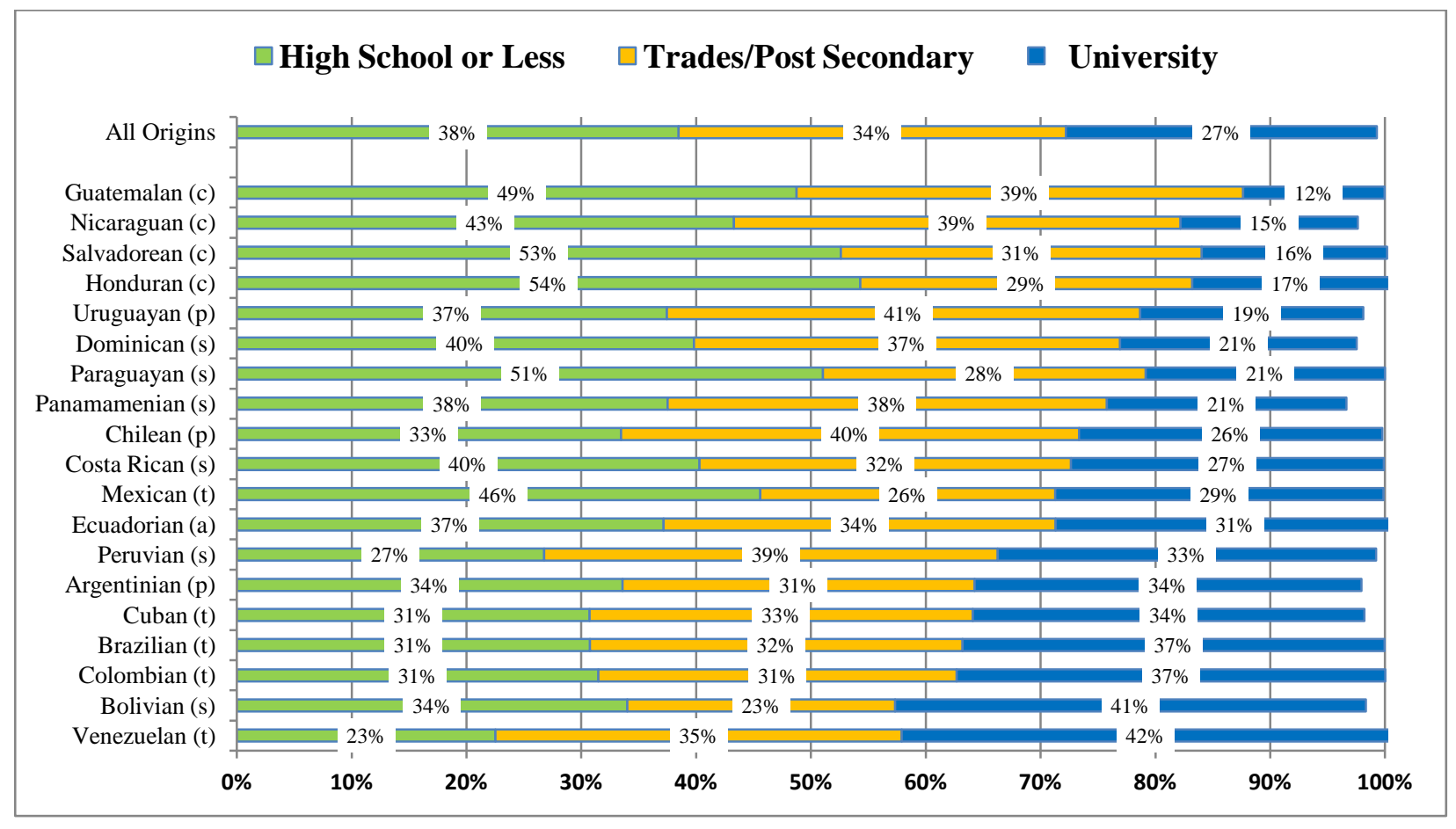

*Symbols: (a)=Andean wave linked, $(\mathrm{p})=$ Coup wave linked, $(\mathrm{c})=$ Central American wave linked, $(\mathrm{t})=$ Technological-Professional wave linked, (s)=Sustaining wave linked. Source: Custom Tabulation EO2695, 2016 Census of Canada 
Chart 13: Educational Composition of Ethnic Immigrant Inflows* from Latin America to Canada, Employed Females aged 25-54, 1981-2016

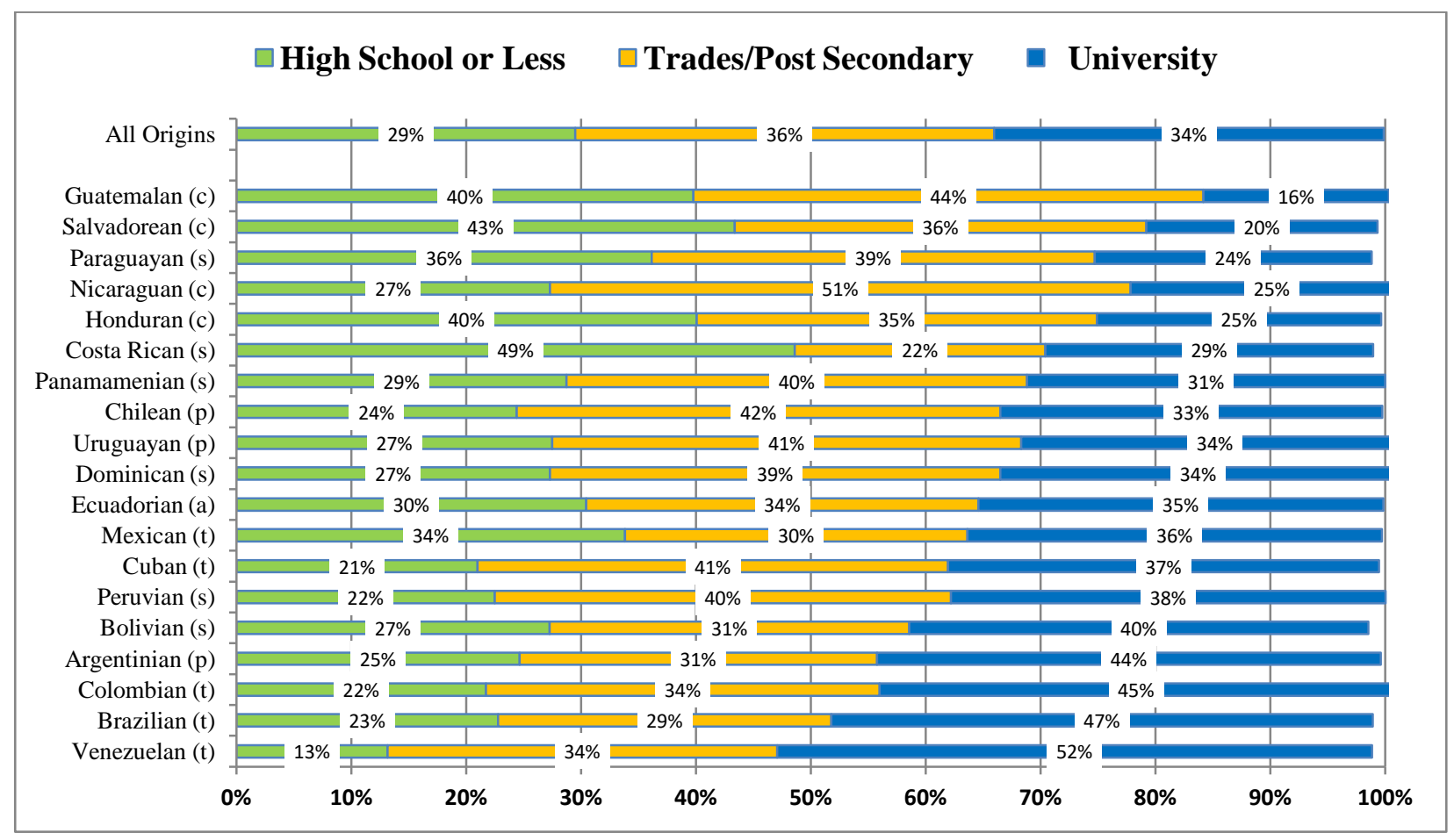

* Symbols: (a)=Andean wave linked, $(\mathrm{p})=$ Coup wave linked, $(\mathrm{c})=$ Central American wave linked, $(\mathrm{t})=$ Technological-Professional wave linked, $(\mathrm{s})=$ Sustaining wave linked. Source: Custom Tabulation EO2695, 2016 Census of Canada

\subsection{Technological-Professional and Coup Wave Members Most Likely to Work in Professional and Managerial Types of Occupations; Women gravitate towards Sales and Services-related Types of Occupations}

The last exploration focused on the occupational niche locations of Latino workers at the time of the 2016 Census. Occupational locations are important as they are proxies for economic integration to primary and secondary labour markets in Canada as well as to potential structural disadvantages in income locations within these markets. Charts 14 and 15 present this information for male and female workers using the NOC2016 (National Occupational Classification System). Overall, the proportions of Latino males and females in the Professional-Managerial categories were found not that dissimilar ( $44 \%$ for males and $40 \%$ for females) but females gravitated more towards Sales and Services type of occupations compared to males (45\% to $24 \%$ ). The charts also revealed that three out of four (76\%) Venezuelan male immigrants (i.e. Technological-Professional wave linked) worked in Professional-Managerial types of occupations. Proportions among Argentinian,

Brazilian, Peruvian, Uruguayan, and Colombian males surpassed the 40\% mark. Among females, there was a lesser degree of variation in percentages in terms of representations in both Professional\&Managerial and Sales\&Services sectors compared to males. On the other side of the occupational spectrum, $64 \%$ of Ecuadorian male immigrants (i.e. Andean wave linked) were found working in manual labour occupations such as trades, resources, and manufacturing. At least half of Dominican and Salvadorean immigrants also worked in the same type of occupations (50\% and $51 \%$ respectively) 


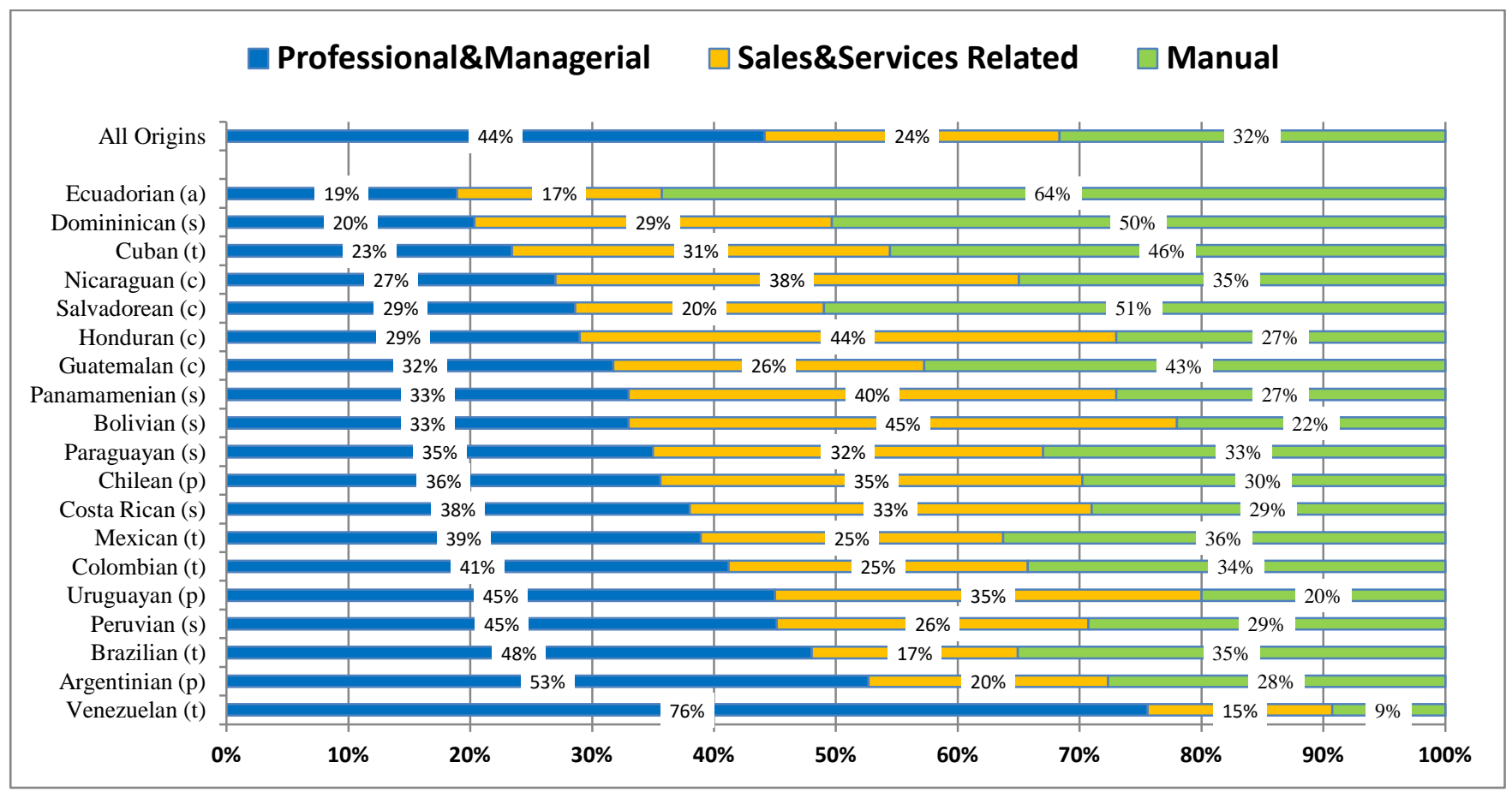

Classifications based on the 2016 NOC system. Professional Managerial comprise managerial, business and science-related occupations, Sales\&Services Related include also Health, Education, Government and Arts, Manual comprise trades manufacturing, trades, and resource-related occupations. Symbols: (a) =Andean wave linked, $(\mathrm{p})=$ Coup wave linked, $(\mathrm{c})=$ Central American wave linked, $(\mathrm{t})=$ Technological-Professional wave linked, (s)= Sustaining wave linked. Source: Custom Tabulation EO3181, 2016 Census of Canada

Chart 15: Occupational Composition of Ethnic Immigrant Inflows* from Latin America to Canada, Employed Females aged 25-54, 1981-2016

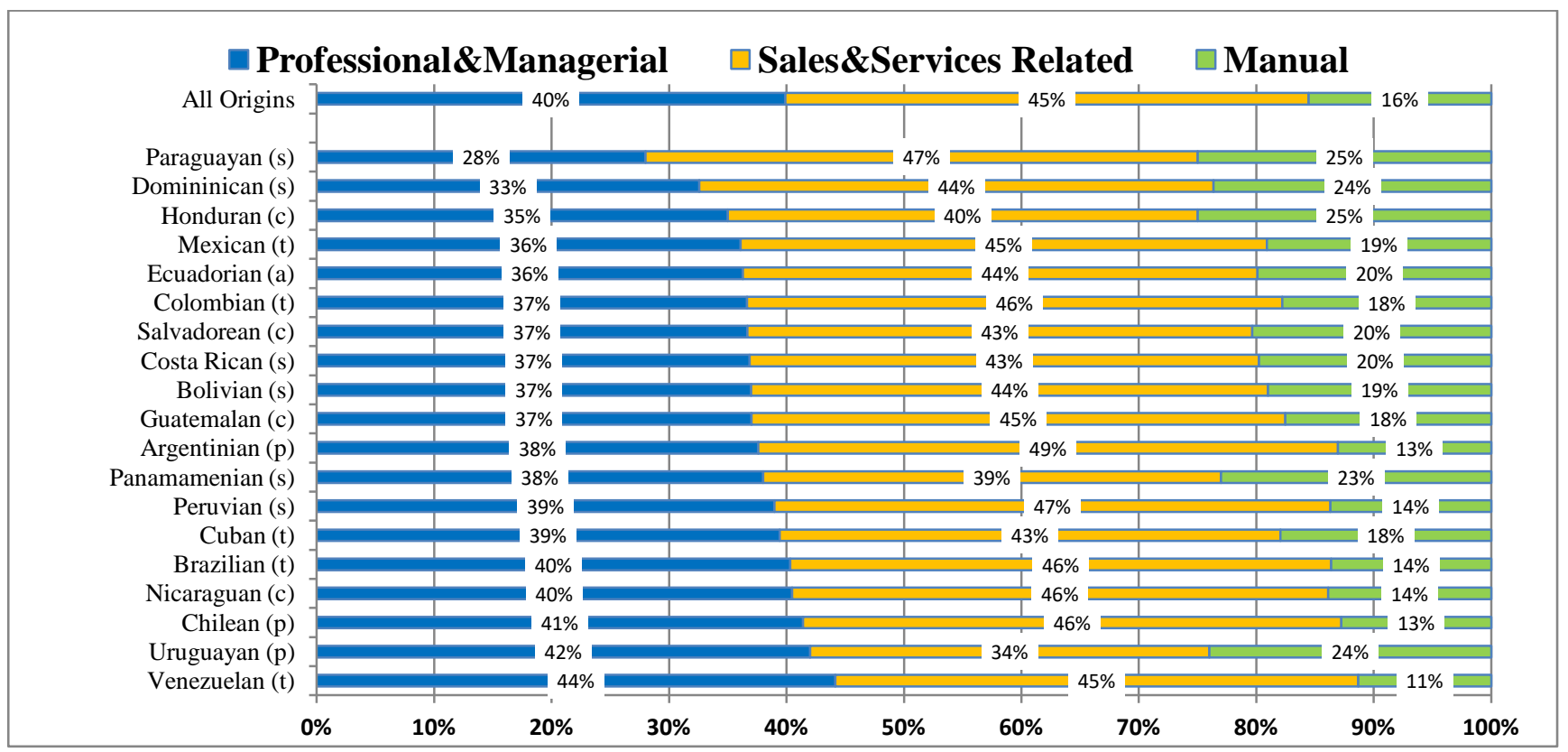

* Classifications based on the 2016 NOC system. Professional Managerial comprise managerial, business and science-related occupations, Sales\&Services Related include also Health, Education, Government and Arts, Manual comprise trades manufacturing, trades, and resource-related occupations. Symbols: (a) =Andean wave linked, $(\mathrm{p})=$ Coup wave linked, $(\mathrm{c})=$ Central American wave linked, $(\mathrm{t})=$ Technological-Professional wave linked, (s)= Sustaining wave linked. Source: Custom Tabulation EO3181, 2016 Census of Canada 


\subsection{Post-Explorations Reflections}

Data explorations carried out with both immigration and 2016 Census data indicate that the Latin Immigration to Canada is a very diverse human aggregate representing cultures from many nations, traditions, languages, and geographical regions of the continent (SC, 2007; SC, 2017). This migration has contributed to the extraordinary growth of the Latino population in the last decades due to steady international immigration inflows and additional children being born within the country. According to the 2016 Census, the total number of individuals reporting single or multiple Latin American and/or Spanish ethnic origins approached a million individuals (976.3 thousand). This figure represents approximately $3 \%$ of the total Canadian population.

Between the 2006 and 2016 Censuses, the annual growth of the Latin American population was estimated at around $4.7 \%$.

The historical moments of Latin American immigration are not only tied to economic and political crises occurring in the region but also to Canada's efforts in meeting its manpower needs and international commitments to protect refugees and other vulnerable populations in times of societal turmoil. Latino immigrants are represented in all immigration class categories such as independent, family, and refugee ones. Immigration statistics indicate that, between 1965 and 2015, five major historical waves of immigration and supporting waves have contributed to the demographic bases of the growth of the community in Canada (Eurolatino or Lead, Andean, Coup, Central American, and Technological-Professional). One additional supporting wave also buttressed the presence of Latin American immigrants in Canada. Some Latino communities emerged as the demographic product of predominantly refugee waves (e.g. Chilean, Salvadorean and Colombian) others did so through the combination of economic (e.g. Mexican, Brazilian, Venezuelan, and Peruvian) and/or family-related immigrant arrivals (e.g. Ecuadorian and Dominicans). Both Spanish and Lusophone speakers (e.g. Brazilians) of Latin America share similar chapters of what Wertsch and Roediger (2008) call the "collective memory" of communities which ranges from escaping economic, health, and environmental crises to coups, insurrections, and civil war.

The first point of reflection of these data explorations refers to the impact of Canada's selection criteria on the economic integration outcomes of Latinos in Canada. Canada's immigrant selection process is a "hybrid" one (see Papadimitriou et. al, 2008). It combines streams defined by a point system of selection based on education, age, experience, and language abilities (e.g. economic class immigrants) and those based on family reunification and humanitarian-related obligations ${ }^{16}$. The latter is the "social" stream of immigration such as family and refugee class type of immigrants. Like other countries such as Australia, the U.K, New Zealand, Canada also allows many of those who served as temporary immigrants to attain permanent status after several years of employment in these countries. Given that the social streams of the immigration process are not selected by the point system, a differential process of human capital accumulation has been created and reproduced over time. Census statistics suggest that economic class immigrants from the various immigrant historical waves have benefited the most from this process by accessing more easily "primary" Canadian labour markets (Hernandez and Mata, 2021). In contrast, members of predominantly "social streams" have struggled and gravitated

\footnotetext{
${ }^{16}$ Immigrant class status in Canada determines access to social services and is critical in the early stages of settlement.
} 
towards "secondary" labour markets ${ }^{17}$. Differences in the occupational outcomes observed among different wave members (e.g. Technological-Professional vs. Central American) can be linked to the long-term consequences of their status at entry in Canada.

The second point of reflection refers to the "dual" character of the more recent fifth Technological-Professional wave of Latino immigration to Canada. This wave has brought to Canada individuals of dissimilar profiles such as a Brazilian engineer entering as a business class immigrant, an asylum seeker from Colombia, a temporary worker from Mexico, and/or a visa overstayer from Venezuela or Cuba. This paper has focused its attention on immigrants admitted as permanent residents, but it is clear that the fifth wave is also fueled by individuals of past "irregular" status in Canada. Permanent status confers formal access to rights and entitlements but is associated with socioeconomic mobility. For those who do not manage to regularize their status in Canada after a certain period, scholars warn there is a danger that they become part of a low-paid underclass of "precarious" legal status workers (Basok, Belanger and Rivas, 2014; Goldring and Landolt, 2021). A "precarious" legal status is generated in many ways. For instance, refugee claimants can apply for a temporary work permit and have formal access to education and basic health services while waiting for a final decision. If their claim is denied, they are excluded from access to services. Tourists and visitors do not have access to work permits or social services. In light of these considerations it is important for future research about Latino immigrants to undertake separate analyses of economic and social integration outcomes for the two basic population streams of the fifth wave (e.g. those entering directly as permanent residents vs. those entering as temporary workers, asylum seekers, visitors, students, etc.)

Finally, the study of how Latino immigrants of the various historical waves economically and socially have integrated into Canada is a complex process that requires both quantitative and qualitative studies to assess the many factors shaping multiple outcomes. Among the various challenges are dealing with a highly diverse group, composed of people coming from many different countries and under different conditions of admission, with diverse socio-demographic and ethnic characteristics. Ensuring employment regardless of human capital endowments, the removal of linguistic and racial discrimination obstacles, and the recognition of international credentials and experience are part of the priority list of policy interventions to ensure adequate integration of Latino to Canadian labour markets. Latino immigrants are a vital labour force group today given Canada's population aging trends and the present pandemic conditions affecting Canada.

17 While primary markets are composed of specialized, higher paid jobs and employment stability and mobility, secondary markets consist mostly of low-paid, low-status jobs that offer little protection and are usually dead-end. 


\section{REFERENCES}

Alcala, P.R, Colorado, M., Diaz, P., and Osorio, A. (2008). Forced Migration of Colombians: Canada. Corporacion Region and B.C. School of Social Work Publishers.

Anderson, G.M. (1981). The Linguistic Imperative and Spanish Speaking Immigrants». Paper presented at the Canadian Ethnology Society meeting, Ottawa, Canada.

Armony, V. (2014). Latin American Communities in Canada: Trends in Diversity and Integration. Canadian Ethnic Studies 46 (3): 7-34. https://doi.org/10.1353/ces.2014.0043

Basok, T. (1983). Models of Successful Leadership: A Case Study of Chilean Immigrants in Toronto». M.A. Thesis. York University

Basok, T., Bélanger, D., and Rivas H.E. (2014). Deportability, Discipline, and Agency: Migrant Agricultural Workers in Southwestern Ontario. Journal of Ethnic and Migration Studies 40(9):1394-1413.

Bonavia, G. (1977). Focus on Canadian Immigration, Ottawa: Department of Manpower and Immigration.

Clarke, J., and Anderson, G.M. (1973). Double Hyphenated Canadians: Spanish Speaking Immigrants of German Background in the Kitchener-Waterloo Urban Area of Ontario. Paper presented at the Canadian Sociology and Anthropology Meeting, Kingston, Ontario.

Diab, S. (2015). Fear and (In) Security: The Canadian Government's Response to the Chilean Refugees, Refuge: Canada's Journal on Refugees 31 (2): 51-62

Duran, M. (1980). Life in Exile: Chileans in Canada. Multiculturalism Ill, (4).

ECLAC- Economic Commission for Latin America and the Caribbean (2019), Social Panorama of Latin America, 2018, (LC/PUB.2019/3-P), Santiago, 2019.CEPAL.

Garay, E. (2000). Social economic and demographic profile of the Hispanic community. Toronto: Hispanic Development Council.

Hanff, G. (1979). "Decision making under pressure: A study of the admittance of Chilean refugees by Canada." North/South 6 (8): 116-135.

Hernandez, A. and Mata, F. (2021). Occupational Niche Locations of Canada's Latin American Workforce: Some Observations and Reflections on the Census Statistics, paper presented to the Canadian Sociological Meetings, June 2021, University of Edmonton, Alberta. 
Humanez Blanquicett, E. (2019). Une histoire de la communauté colombienne de Montréal, Memoires des Montrealais, retrieved from https://ville.montreal.qc.ca/memoiresdesmontrealais/

Ferris, E. (1987). The Central American Refugees. New York City: Praeger Press.

Goldring, L., Berinstein, C. and Bernhard, J.K. (2009). Institutionalizing precarious migratory status in Canada. Citizenship Studies 13 (3): 239-265. https://doi.org/10.1080/13621020902850643

Goldring, L., and Landolt, P. (2011). Caught in the Work-Citizenship Matrix: the Lasting Effects of Precarious Legal Status on Work for Toronto Immigrants. Globalizations 8 (3):325-341.

Goldring, L. and Landolt, P. (2021): From illegalised migrant toward permanent resident: assembling precarious legal status trajectories and differential inclusion in Canada, Journal of Ethnic and Migration Studies, DOI:

10.1080/1369183X.2020.1866978

GC (Government of Canada). (2018). "Find out about Electronic Travel Authorization (eTA)." Last Modified March 22, accessed April ,2020. https://www.canada.ca/en/immigration-refugees-citizenship/services/visitcanada/eta/facts.html.

Kehler, T. (2019). Low Mennonite Migrants' Experience Migrants' Experience of Social Exclusion and the Mediation of Social Inclusion in Southern Manitoba, paper presented to the Strangers in Their Homeland Conference, University of Manitoba, Winnipeg -Manitoba, November 2019.

Kowalchuk, L. (1999). Salvadorans. In Encyclopedia of Canada's Peoples, edited by R. P. Magocsi, $1109-1115$. Toronto: University of Toronto Press.

Landolt, P., and Goldring, L. (2010). "Political Cultures and Transnational Social Fields: Chilean, Colombian and Canadian Activists in Toronto " Global Networks: A Journal of Transnational Affairs 10 (4): 443-466.

Landlot, P., Bernhard, J.K., and Goldring, L. (2011) Agenda Setting and Immigrant Politics: The Case of Latin Americans in Toronto. American Behavioral Scientist 55, no. 9 (August 2011): 1235-1266.

Mata, F. (1985). Latin American Immigration to Canada: Some Reflections on the Immigration Statistics.” Canadian Journal of Latin American and Caribbean Studies, 10, no. 20 (1985): 27-42.

Mata, F. (2020). Exploring the Ethnic Immigrant Inflows from Latin America to Canada: 1981-2016. Paper presented at the 2020 REDAN-UNAM conference, Mexico City, May 18-20.

McLaughlin, J. and Hennebry, J. (2013). Pathways to Precarity: Structural Vulnerabilities and Lived Consequences in the Everyday Lives of Migrant Farmworkers in Canada. In L. Goldring and P. Landolt (Eds.), Producing and Negotiating NonCitizenship: Precarious Legal Status in Canada. University of Toronto Press, Toronto: 174-194. 
Peddie, F. (2018). Young, Well Educated and Adaptable People: Chilean Exiles, Identity and Daily Life in Canada, 1973 to the Present Day, Unpublished Ph.D. Dissertation, Graduate Program in History, York University, Toronto, retrieved from https:// yorkspace.library.yorku.ca

Papademetriou, D.G., Somervillle, W., and Tanaka, H. (2008). Hybrid Immigrant-Selection Systems: The Next Generation of Economic Migration Schemes, Washington D.C: Migration Policy Institute

Piche, V. (2019) Política migratoria canadiense en un contexto global. ¿El modelo es realmente “excepcional”? in "Las Nuevas Politicas Migratorias Canadienses, Governanza neoliberal y manejo de la otredad", Lara Flores, S.M;

Pantaleón, J. Martin, P.M (coordinadores), UNAM, Universidad de Montreal Publication, Mexico City, p.23-54

Raska, J. (2020). (1973). Canada's Response to the Chilean Refugee.” Research Collection 6. Accessed March 27, 2021.

Robinson, W.G. (1983). Illegal Immigrants Issue Paper: Ottawa: Employment and Immigration Canada.

SC (Statistics Canada). (2017). Ethnic and cultural origins of Canadians: Portrait of a rich heritage, Census of Population 2016, Catalogue no. 98-200-X2016016 ISBN 978-0-660-20339-3

Simmons, Alan B. (1993). Latin American Migration to Canada: New Linkages in the Hemispheric Migration and Refugee Flow System. International Journal 48, no. 2: 282-309.

SC (Statistics Canada) (2007). The Latin American Community in Canada. Available at: https://www150.statcan.gc.ca/n1/pub/89-621-x/89-621-x2007008-eng.htm.

Veronis, L. (2010): Immigrant Participation in the Transnational Era: Latin Americans' Experiences with Collective Organising in Toronto, Journal of International Migration and Integration 11(2):173-192

Vendramin, G. (2013). Occupational Mobility of Brazilians in Brazilian Immigrants in Segmented Labour Markets, Major Research Paper Presented in partial fulfillment of the requirements for the degree of Master of Arts, Toronto: Ryerson University

Villegas, Paloma E. (2020). North of El Norte: Illegalized Mexican Migrants in Canada. Vancouver: UBC Press.

Wertsch, J.V and Roediger, H.L (2008). Collective memory: Conceptual foundations and theoretical approaches, MEMORY, 2008, 16 (3), 318326 
Table A-1: Permanent Residents by Year of Admission*, Countries of Citizenship of Latin American Immigrants, Canada 1965-2015

\begin{tabular}{|c|c|c|c|c|c|c|c|c|c|}
\hline & Argentina & Bolivia & Brazil & Chile & Colombia & Costa Rica & Cuba & Dominican & Ecuador \\
\hline All & 30,210 & 4,176 & 40,667 & 37,005 & 83,417 & 5,499 & 22,756 & 13,030 & 20,511 \\
\hline 1965 & 499 & 43 & 583 & 55 & 22 & 19 & 80 & 67 & 15 \\
\hline 1966 & 506 & 33 & 615 & 101 & 90 & 31 & 12 & 58 & 27 \\
\hline 1967 & 532 & 13 & 728 & 122 & 45 & 79 & 16 & 79 & 70 \\
\hline 1968 & 472 & 57 & 495 & 180 & 135 & 55 & 14 & 57 & 45 \\
\hline 1969 & 489 & 44 & 586 & 228 & 195 & 79 & 99 & 18 & 62 \\
\hline 1970 & 318 & 53 & 530 & 248 & 248 & 53 & 22 & 61 & 28 \\
\hline 1971 & 298 & 44 & 431 & 365 & 265 & 95 & 90 & 20 & 199 \\
\hline 1973 & 1,330 & 88 & 591 & 517 & 961 & 100 & 16 & 65 & 1,182 \\
\hline 1974 & 1,378 & 82 & 591 & 2,067 & 1,083 & 33 & 57 & 86 & 1,871 \\
\hline 1975 & 903 & 27 & 502 & 3,010 & 1,003 & 35 & 12 & 47 & 1,705 \\
\hline 1976 & 939 & 71 & 411 & 2,561 & 768 & 11 & 72 & 44 & 1,110 \\
\hline 1977 & 929 & 43 & 398 & 2,123 & 531 & 23 & 78 & 83 & 531 \\
\hline 1978 & 708 & 95 & 272 & 1,961 & 381 & 58 & 11 & 70 & 436 \\
\hline 1979 & 498 & 40 & 249 & 1,287 & 332 & 25 & 71 & 24 & 291 \\
\hline 1980 & 368 & 44 & 211 & 1,233 & 266 & 28 & 106 & 40 & 238 \\
\hline 1981 & 426 & 52 & 220 & 1,069 & 326 & 35 & 41 & 53 & 207 \\
\hline 1983 & 241 & 49 & 139 & 781 & 244 & 51 & 104 & 88 & 155 \\
\hline 1984 & 237 & 38 & 145 & 681 & 235 & 75 & 101 & 97 & 179 \\
\hline 1985 & 196 & 44 & 130 & 533 & 214 & 113 & 115 & 84 & 208 \\
\hline 1986 & 213 & 79 & 205 & 633 & 257 & 79 & 102 & 307 & 240 \\
\hline 1987 & 519 & 165 & 244 & 1,454 & 376 & 116 & 139 & 446 & 344 \\
\hline 1988 & 374 & 63 & 394 & 990 & 352 & 104 & 90 & 358 & 265 \\
\hline 1989 & 538 & 68 & 650 & 1,023 & 439 & 92 & 122 & 409 & 278 \\
\hline 1990 & 678 & 71 & 650 & 1,286 & 614 & 99 & 135 & 363 & 552 \\
\hline 1991 & 763 & 214 & 877 & 1,749 & 652 & 156 & 158 & 517 & 643 \\
\hline 1992 & 1,023 & 247 & 1,066 & 1,175 & 582 & 216 & 220 & 557 & 644 \\
\hline 1993 & 1,022 & 180 & 866 & 697 & 464 & 184 & 374 & 646 & 547 \\
\hline 1994 & 366 & 75 & 566 & 352 & 375 & 83 & 360 & 432 & 431 \\
\hline 1995 & 380 & 61 & 572 & 273 & 371 & 89 & 421 & 276 & 368 \\
\hline 1996 & 396 & 96 & 586 & 244 & 381 & 118 & 508 & 306 & 310 \\
\hline 1997 & 391 & 43 & 591 & 325 & 578 & 135 & 566 & 285 & 317 \\
\hline 1998 & 349 & 33 & 531 & 376 & 929 & 103 & 531 & 210 & 295 \\
\hline 1999 & 318 & 42 & 626 & 397 & 1,306 & 100 & 696 & 254 & 291 \\
\hline 2003 & 1,745 & 59 & 839 & 347 & 4,317 & 105 & 876 & 233 & 362 \\
\hline 2004 & 1,592 & 85 & 917 & 383 & 4,565 & 165 & 868 & 270 & 417 \\
\hline 2005 & 1,153 & 134 & 969 & 384 & 6,424 & 188 & 999 & 297 & 491 \\
\hline 2006 & 847 & 139 & 1,181 & 427 & 6,535 & 279 & 1,064 & 289 & 524 \\
\hline 2007 & 620 & 107 & 1,745 & 530 & 5,358 & 281 & 1,349 & 309 & 419 \\
\hline 2008 & 540 & 142 & 2,137 & 350 & 5,449 & 246 & 1,300 & 430 & 437 \\
\hline 2009 & 467 & 214 & 2,510 & 376 & 4,655 & 217 & 1,426 & 362 & 374 \\
\hline 2010 & 459 & 180 & 2,598 & 340 & 5,218 & 190 & 963 & 455 & 353 \\
\hline 2011 & 278 & 86 & 1,508 & 174 & 4,366 & 149 & 961 & 736 & 348 \\
\hline 2012 & 263 & 83 & 1,641 & 291 & 3,736 & 183 & 1,301 & 604 & 279 \\
\hline 2013 & 282 & 107 & 1,712 & 273 & 3,632 & 122 & 1,402 & 589 & 418 \\
\hline 2014 & 214 & 95 & 1,916 & 299 & 2,859 & 165 & 1,079 & 445 & 334 \\
\hline 2015 & 237 & 74 & 1,750 & 258 & 2,181 & 121 & 827 & 602 & 215 \\
\hline
\end{tabular}

* Highlighted counts =1,000 plus. Sources: (1) 1965-1979: Table 14, Immigration Statistics, Employment and Immigration Canada, (2) 19802015: Permanent Residents - Ad Hoc IRCC (Specialized Datasets)- Admissions of Permanent Residents by Country of Citizenship (Q1-Q2 2016 ranking), 1980 - Q2 2016. Note: some figures may be rounded. 
Table A-2: Permanent Residents by Year of Admission*, Countries of Citizenship of Latin American Immigrants, Canada 1965-2015

\begin{tabular}{|c|c|c|c|c|c|c|c|c|c|c|}
\hline & El Salvador & Guatemala & Honduras & Mexico & Nicaragua & Panama & Paraguay & Peru & Uruguay & Venezuela \\
\hline All & 57,113 & 20,649 & 9,456 & 73,743 & 13,145 & 4,069 & 4,746 & 36,533 & 10,720 & 26,658 \\
\hline 1965 & 51 & 40 & 98 & 146 & 21 & 91 & 187 & 81 & 110 & 312 \\
\hline 1966 & 72 & 24 & 61 & 110 & 68 & 31 & 176 & 15 & 205 & 308 \\
\hline 1967 & 54 & 48 & 94 & 308 & 69 & 97 & 308 & 38 & 168 & 392 \\
\hline 1968 & 10 & 74 & 51 & 247 & 49 & 34 & 112 & 22 & 112 & 202 \\
\hline 1969 & 80 & 73 & 52 & 358 & 38 & 22 & 195 & 163 & 423 & 261 \\
\hline 1970 & 95 & 23 & 84 & 460 & 98 & 14 & 111 & 283 & 672 & 248 \\
\hline 1971 & 96 & 40 & 16 & 398 & 39 & 85 & 166 & 332 & 464 & 199 \\
\hline 1973 & 86 & 30 & 14 & 665 & 27 & 56 & 174 & 517 & 665 & 67 \\
\hline 1974 & 29 & 91 & 58 & 689 & 95 & 30 & 155 & 115 & 689 & 155 \\
\hline 1975 & 28 & 95 & 95 & 803 & 44 & 18 & 173 & 150 & 702 & 182 \\
\hline 1976 & 90 & 15 & 18 & 768 & 69 & 57 & 207 & 136 & 512 & 126 \\
\hline 1977 & 23 & 21 & 94 & 796 & 17 & 98 & 191 & 194 & 332 & 124 \\
\hline 1978 & 100 & 10 & 43 & 545 & 36 & 81 & 196 & 168 & 310 & 129 \\
\hline 1979 & 49 & 43 & 16 & 415 & 81 & 60 & 175 & 111 & 249 & 117 \\
\hline 1980 & 110 & 114 & 26 & 409 & 18 & 13 & 45 & 317 & 128 & 103 \\
\hline 1981 & 295 & 108 & 33 & 394 & 21 & 8 & 26 & 456 & 132 & 117 \\
\hline 1983 & 2,587 & 366 & 68 & 490 & 55 & 10 & 40 & 241 & 105 & 124 \\
\hline 1984 & 2,666 & 598 & 65 & 509 & 126 & 11 & 48 & 306 & 90 & 142 \\
\hline 1985 & 2,769 & 975 & 69 & 425 & 468 & 17 & 36 & 328 & 92 & 165 \\
\hline 1986 & 3,106 & 1,265 & 81 & 667 & 670 & 16 & 34 & 628 & 137 & 179 \\
\hline 1987 & 3,558 & 1,060 & 135 & 813 & 1,073 & 26 & 72 & 843 & 269 & 229 \\
\hline 1988 & 2,720 & 702 & 111 & 916 & 969 & 21 & 53 & 1,237 & 99 & 279 \\
\hline 1989 & 2,955 & 773 & 138 & 1,017 & 705 & 108 & 48 & 1,667 & 144 & 304 \\
\hline 1990 & 4,384 & 1,023 & 187 & 1,193 & 710 & 116 & 56 & 1,384 & 111 & 344 \\
\hline 1991 & 7,124 & 2,156 & 688 & 1,134 & 1,517 & 658 & 51 & 1,522 & 229 & 487 \\
\hline 1992 & 5,670 & 1,906 & 840 & 1,189 & 2,062 & 611 & 94 & 1,632 & 299 & 610 \\
\hline 1993 & 2,977 & 1,392 & 551 & 1,139 & 1,069 & 420 & 75 & 1,274 & 437 & 490 \\
\hline 1994 & 1,217 & 757 & 291 & 776 & 261 & 103 & 46 & 993 & 125 & 334 \\
\hline 1995 & 722 & 640 & 270 & 758 & 251 & 63 & 39 & 827 & 164 & 402 \\
\hline 1996 & 736 & 655 & 299 & 1,234 & 248 & 73 & 38 & 845 & 171 & 520 \\
\hline 1997 & 603 & 519 & 225 & 1,689 & 195 & 70 & 30 & 676 & 117 & 686 \\
\hline 1998 & 477 & 358 & 167 & 1,379 & 124 & 37 & 25 & 493 & 87 & 489 \\
\hline 1999 & 424 & 287 & 173 & 1,679 & 144 & 22 & 34 & 560 & 93 & 464 \\
\hline 2002 & 473 & 242 & 143 & 1,894 & 69 & 49 & 60 & 854 & 91 & 524 \\
\hline 2003 & 446 & 179 & 105 & 1,754 & 88 & 54 & 88 & 1,023 & 103 & 699 \\
\hline 2004 & 441 & 217 & 133 & 2,257 & 67 & 38 & 74 & 1,457 & 130 & 1,224 \\
\hline 2005 & 435 & 190 & 166 & 2,837 & 79 & 57 & 75 & 1,653 & 217 & 1,211 \\
\hline 2006 & 429 & 230 & 165 & 2,844 & 96 & 73 & 88 & 1,473 & 175 & 1,192 \\
\hline 2007 & 926 & 256 & 165 & 3,240 & 76 & 63 & 98 & 1,490 & 147 & 1,335 \\
\hline 2008 & 1,114 & 263 & 185 & 2,854 & 123 & 52 & 94 & 1,094 & 159 & 1,240 \\
\hline 2009 & 841 & 264 & 169 & 3,092 & 114 & 73 & 91 & 1,884 & 99 & 1,352 \\
\hline 2010 & 768 & 265 & 385 & 3,862 & 91 & 65 & 89 & 1,282 & 93 & 998 \\
\hline 2011 & 692 & 289 & 538 & 3,948 & 122 & 49 & 83 & 886 & 81 & 1,451 \\
\hline 2012 & 641 & 358 & 436 & 4,227 & 106 & 34 & 55 & 787 & 47 & 1,366 \\
\hline 2013 & 637 & 348 & 350 & 3,995 & 96 & 43 & 66 & 683 & 58 & 1,022 \\
\hline 2014 & 700 & 317 & 402 & 4,477 & 118 & 59 & 38 & 712 & 43 & 1,483 \\
\hline 2015 & 656 & 240 & 422 & 3,231 & 96 & 39 & 36 & 559 & 50 & 929 \\
\hline
\end{tabular}

* Highlighted: counts =1,000 plus. Sources: (1) 1965-1979: Table 14, Immigration Statistics, Employment and Immigration Canada, (2) 19802015: Permanent Residents - Ad Hoc IRCC (Specialized Datasets)- Admissions of Permanent Residents by Country of Citizenship (Q1-Q2 2016 ranking), 1980 - Q2 2016. Note: some figures may be rounded. 
Table A-3: Non-Permanent Residents in the 2016 Census by Ethnic Origins*, Gender and Educational Characteristics, Canada 2016

\begin{tabular}{|c|c|c|c|c|c|c|c|c|}
\hline Ethnic Origins & N Total - & N Male & $\begin{array}{l}\mathrm{N} \\
\text { Female }\end{array}$ & $\begin{array}{l}\text { \% } \\
\text { Male }\end{array}$ & $\begin{array}{l}\text { \% } \\
\text { Female }\end{array}$ & $\begin{array}{l}\% \\
\text { Secondary } \\
\text { education } \\
\text { or below }\end{array}$ & $\begin{array}{l}\text { \% } \\
\text { Trades, } \\
\text { College. } \\
\text { PS } \\
\text { Certificate }\end{array}$ & $\begin{array}{l}\% \\
\text { University } \\
\text { Education }\end{array}$ \\
\hline Mexican (t) & 8,620 & 4,905 & 3,715 & $57 \%$ & $43 \%$ & $48 \%$ & $12 \%$ & $41 \%$ \\
\hline Brazilian (t) & 4,935 & 2,330 & 2,605 & $47 \%$ & $53 \%$ & $26 \%$ & $11 \%$ & $63 \%$ \\
\hline Colombian (t) & 3,310 & 1,605 & 1,700 & $48 \%$ & $52 \%$ & $42 \%$ & $11 \%$ & $47 \%$ \\
\hline Venezuelan (t) & 2,215 & 1,030 & 1,195 & $47 \%$ & $53 \%$ & $22 \%$ & $14 \%$ & $65 \%$ \\
\hline Chilean (p) & 1,050 & 565 & 480 & $54 \%$ & $46 \%$ & $22 \%$ & $13 \%$ & $64 \%$ \\
\hline Peruvian (s) & 775 & 355 & 415 & $46 \%$ & $54 \%$ & $35 \%$ & $19 \%$ & $45 \%$ \\
\hline Guatemalan (c) & 750 & 640 & 110 & $85 \%$ & $15 \%$ & $81 \%$ & $12 \%$ & $7 \%$ \\
\hline Cuban (t) & 695 & 325 & 370 & $47 \%$ & $53 \%$ & $38 \%$ & $20 \%$ & $42 \%$ \\
\hline Salvadorean (c) & 685 & 355 & 330 & $52 \%$ & $48 \%$ & $58 \%$ & $20 \%$ & $22 \%$ \\
\hline Ecuadorian (c) & 630 & 320 & 315 & $51 \%$ & $49 \%$ & $40 \%$ & $21 \%$ & $40 \%$ \\
\hline Argentinian (p) & 570 & 260 & 310 & $46 \%$ & $54 \%$ & $36 \%$ & $15 \%$ & $50 \%$ \\
\hline Costa Rican (s) & 355 & 200 & 155 & $56 \%$ & $44 \%$ & $42 \%$ & $30 \%$ & $28 \%$ \\
\hline Honduran (c) & 305 & 205 & 100 & $67 \%$ & $33 \%$ & $56 \%$ & $18 \%$ & $28 \%$ \\
\hline Bolivian (s) & 150 & 55 & 90 & $37 \%$ & $63 \%$ & $27 \%$ & $20 \%$ & $60 \%$ \\
\hline Nicaraguan (s) & 130 & 65 & 65 & $50 \%$ & $50 \%$ & $50 \%$ & $8 \%$ & $27 \%$ \\
\hline Uruguayan (p) & 90 & 50 & 45 & $56 \%$ & $44 \%$ & $61 \%$ & $17 \%$ & $22 \%$ \\
\hline Panamanian (s) & 80 & 35 & 45 & $44 \%$ & $56 \%$ & $38 \%$ & $19 \%$ & $56 \%$ \\
\hline Paraguayan (c) & 70 & 45 & 20 & $64 \%$ & $36 \%$ & $64 \%$ & $21 \%$ & $14 \%$ \\
\hline Total & 25,415 & 13,345 & 12,065 & $53 \%$ & $47 \%$ & $44 \%$ & $17 \%$ & $40 \%$ \\
\hline
\end{tabular}

* Symbols: (a) Andean wave linked, (p)=Coup wave linked, (c) Central American wave linked, (t) Technological-Professional wave linked, (s) Sustaining wave linked. Source: Custom Tabulations EO2695, 2016 Census of Canada 